\title{
A questão tributária e a problemática da arrecadação fiscal em decorrência da mineração industrial na Amazônia
}

Sérgio Roberto Bacury de Lira - Doutorando em Desenvolvimento Sustentável do Trópico Úmido pelo NAEA/UFPA e professor do departamento de economia da UFPA.

\section{Resumo}

A concessão de incentivos fiscais e financeiros foi indispensável para o desenvolvimento da indústria mínerometalúrgica, principalmente no Estado do Pará. O Governo Federal, ao considerar a importância para o país da obtenção de expressivos resultados superavitários no comércio exterior, com o objetivo de reduzir a vulnerabilidade externa da economia brasileira, resolveu premiar a cooperação dos demais entes da federação nesse esforço exportador. A Lei Kandir promoveu a exoneração do ICMS nas operações que destinem mercadorias para o exterior, bem como os serviços prestados a tomadores localizados no exterior. Com isso, Estados e Municípios perderam parcela da arrecadação de seus impostos. Os Municípios foram duplamente prejudicados pela exoneração direta do ISS e pela redução na partilha do produto de arrecadação do ICMS.

\section{Palavras-chave}

Tributação, mineração industrial e economia regional.

\section{Abstract}

The fiscal and financing incentives concessions had been absolutely necessary concerning the development of the mining and metallurgical industry. The Federal Government considering the country importance with expressive foreign trade superávit outcome, with the aim of reducing the foreign vulnerability of the Brazilian economy resolved reward the cooperation evolving other beings of the federation in a export effort. The Kandir law promoted the dispense of the ICMS in the operations destined to foreign goods as well as services located abroad. States and municipalities have been lost parcel of income tax receipts. The municipalities had been double damaged by the ISS direct dispense and product share reduction of the product of collection of the ICMS.

\section{Keywords}

Taxation, mining industry and regional economy. 


\section{INTRODUÇÃO}

Na literatura econômica, a implantação de um empreendimento produtivo, principalmente do segmento industrial, significa a oportunidade de surgimento de inúmeros benefícios no campo socioeconômico, dentre os quais se destaca o aumento da arrecadação tributária. É por meio desse resultado indireto que o governo realiza, de forma direta, os serviços em prol da sociedade, beneficiando-a cumulativamente.

Na Amazônia, desde meados da década de 1960, o governo federal adotou o princípio da isenção ou renúncia fiscal para desenvolver economicamente a região, porque, somente reduzindo os custos de implantação e aumentando os lucros das empresas, seria possível incentivar e atrair os empreendimentos capitalistas para a região. Essa estratégia constituiu-se na chamada "política de desenvolvimento regional", o que obrigou os estados a assumir um papel secundário nesse processo e a adotar as mesmas regras de isenção como forma de garantir os recursos necessários ao desenvolvimento dos seus territórios.

Portanto, diferentemente da forma clássica prevista na literatura econômica, a legislação tributária que o governo federal tem adotado na Amazônia só tem beneficiado os empreendimentos capitalistas na região, impondo enormes sacrifícios aos demais entes federativos, o que é prejudicial para o desenvolvimento socioeconômico regional.

Em vista disso, procurar-se-á averiguar neste trabalho as alterações que se processaram na legislação tributária para viabilizar economicamente a indústria de mineração na Amazônia, mais precisamente nos Estados do Amapá, do Maranhão e do Pará, visto que nessas unidades federativas concentra-se a maior parte dos empreendimentos existentes na região, e demonstrar o impacto dessas alterações na arrecadação fiscal e na capacidade de financiamento do desenvolvimento desses estados e dos municípios mineradores, ou seja, dos municípios onde se encontram instalados esses empreendimentos e dos municípios localizados no entorno desses empreendimentos.

\section{CONDICIONANTES BÁSICOS DAS MODIFICAÇÕES TRIBUTÁRIAS EM BENEFÍCIO DA MINERAÇÃO INDUSTRIAL NA AMAZÔNIA}

A Amazônia sempre foi vista como um celeiro de recursos naturais, sobretudo no que concerne aos recursos minerais. Na verdade, já nos primórdios da colonização brasileira, a região foi "visitada" por aventureiros de origens diversas, que buscavam ouro e pedras preciosas e tentavam a todo custo encontrar o El dorado ou o rio de ouro, transformado em lendas que atravessaram os séculos. 
Mas a estruturação da economia mineral na Amazônia - incluindo as atividades de pesquisa, prospecção, extração, beneficiamento e industrialização de minérios - só foi iniciada na década de 1950, preliminarmente com a viabilização da exploração industrial de manganês na localidade de Serra do Navio, então Território do Amapá; intensificouse a partir da década de 1960, com a descoberta das reservas minerais de bauxita do rio Trombetas, no município de Oriximiná, Estado do Pará, de manganês de Sereno e de Buritirama, no então município de Marabá, no Pará, e de minério de ferro da região dos Carajás, também em Marabá; consolidou-se no período que vai do final dos anos 1970 ao final da década de 1980, com a entrada em operação da exploração de bauxita pela Mineração Rio do Norte (em 1979, no Pará), do minério de ferro pelo Projeto Ferro Carajás (em 1984, no Pará), da produção de alumínio primário pela Alumar (em 1984, no Maranhão) e pela ALBRÁS (em 1985, no Pará), e da extração de manganês de Igarapé Azul pelo complexo pertinente ao Projeto Ferro Carajás (em 1986, no Pará).

A estruturação desse segmento produtivo na região nesse e somente a partir desse período não ocorre, todavia, de forma aleatória no espaço, tampouco surge do nada; decorre de uma série de fatores complexos, mas confluentes, que se evidenciam como determinantes endógenos e exógenos da realidade econômica brasileira e se impõem na realidade amazônica, redefinindo o seu rumo e a trajetória do seu desenvolvimento recente.

De início, portanto, pode-se afirmar que um determinante importante, mas não necessariamente o primeiro na ordem seqüencial que aqui se inicia, até mesmo porque vários determinantes se manifestaram concomitantemente no tempo, refere-se aos interesses e às estratégias do capital estrangeiro, ou seja, das empresas transnacionais, para assegurar a viabilização econômica desse segmento produtivo na região. O interesse pela exploração do manganês do Amapá surgiu por intermédio da Bethlehem Steel, no momento de agudização da guerra fria desencadeada pelos Estados Unidos, e do reconhecimento da importância estratégica do aço para a reconstrução econômica da Europa e da Ásia no período pós segunda guerra mundial.

Portanto, influenciada pela política comercial americana de garantir depósitos expressivos desse minério que ficassem próximos e subordinados ao mercado americano, para não mais depender das reservas da União Soviética, a Bethlehem Steel associou-se a capitais nacionais brasileiros e estruturou uma grande empresa do tipo joint venture ${ }^{1}$ para explorar e exportar o

${ }^{1}$ Uma joint venture é um tipo de consórcio formado por por empresa transnacional e empresa estatal nacional, ou empresa transnacional e empresa privada nacional, ou empresa transnacional, empresa estatal nacional e empresa privada nacional. 
manganês do Amapá ${ }^{2}$. Para tanto, foi imprescindível a participação do governo brasileiro, que assegurou os empréstimos contraídos no U.S. Ex-Im Bank para a formação dessa empresa.

À primeira vista, há três outros importantes determinantes do surgimento da mineração industrial na Amazônia: a existência de abundantes jazidas minerais na região, a participação do capital nacional na estruturação de empreendimentos produtivos e a ação do governo brasileiro, criando garantias e mecanismos para a reprodução do capital no país. No entanto, como esses determinantes ainda serão analisados com maior profundidade mais adiante, não serão aqui destacados com a importância que merecem, até mesmo porque essa junção de interesses e vantagens em benefício da implantação da mineração industrial na região, da forma como se processou nesse momento, ainda não retrata com exatidão o que se pretende demonstrar neste trabalho. Essa forma foi o primeiro manifesto da conjugação de interesses em prol desse setor produtivo na região, mas totalmente desvinculado de qualquer estratégia de desenvolvimento da Amazônia ou de sua inserção mais efetiva na economia mundial.

Esse quadro começou a mudar a partir de meados da década de 60, quando, por um lado, a descoberta de novas e importantes jazidas minerais na região, já descrita anteriormente, aumentou o interesse de outras empresas transnacionais - Alcan, Union Carbide, United State Steel - em também investir na região e, por outro lado, a estratégia de desenvolvimento nacional adotada pelos governos militares pós-64 levou à implementação na região de uma política que privilegiava o seu desenvolvimento com base em um amplo leque de instrumentos, o mais importante dos quais eram os incentivos fiscais, que visavam a facilitar e a atrair o capital privado (nacional e/ou estrangeiro) para a região.

Por conseguinte, com base na conjugação desses interesses recíprocos, iniciou-se um processo que levaria, posteriormente, à formação de novas empresas joint ventures no ramo da indústria mineral na região e, com isso, à inserção da região e da economia nacional no circuito da produção mundial desse setor produtivo. A concretização desse processo, entretanto, só ocorreu efetivamente na década de 70 quando a esses determinantes se associou mais um outro de magnitude e importância similar: os impactos provocados pelos oil-shocks no mercado internacional e, sobretudo, na economia brasileira.

O primeiro choque dos preços do petróleo no mercado internacional (1973-1974) desequilibrou de forma acentuada a balança

\footnotetext{
${ }^{2}$ Os depósitos de manganês do Amapá encontravam-se fisicamente concentrados e espacialmente localizados em uma área distante apenas $32 \mathrm{~km}$ de um porto de águas profundas, portanto, economicamente adequada à sua exploração.
} 
comercial brasileira, principalmente pelo fato de o país constituir-se nessa época em importador por excelência de petróleo; aumentou o endividamento de economias como a brasileira, cujo desenvolvimento mantinha-se baseado em empréstimos internacionais, sobretudo em dólar; estancou a capacidade de financiamento do processo de desenvolvimento nacional baseado na política de substituição de importações industriais vigente no país; conseqüentemente, agravou o problema cambial brasileiro. Portanto, para superar esse quadro, era necessário adotar urgentemente uma política que privilegiasse a geração ou a economia de divisas estrangeiras, por meio da exportação, da substituição de importações ou da atração de capitais de risco ou de empréstimos provenientes do exterior (IDESP, 1988).

Como essa crise ocorreu no momento em que o crescimento econômico brasileiro tinha atingido o seu patamar mais elevado, considerado inclusive como a fase do "milagre brasileiro", e era inaceitável e politicamente inviável para os governos militares estancar ou desacelerar o ritmo de crescimento da economia nacional vigente nessa época, o governo estabeleceu uma nova política econômica, consubstanciada, no âmbito nacional, no II Plano Nacional de Desenvolvimento (II PND) e reproduzida, no âmbito regional, por meio do II Plano de Desenvolvimento da Amazônia (II PDA).

Esses Planos, conjugados em seus propósitos e metas, definiram que a região contribuiria para a manutenção de altas taxas de crescimento do PIB por meio de ampla contribuição em relação ao setor de comércio exterior. Em outras palavras, aproveitando-se de suas "vantagens comparativas, a região iria contribuir significativamente através de geração de divisas, resultantes de exportações, de economia de divisas, produzindo insumos básicos para o Centro-Sul do país, e pela liberação de produto exportável comprometida pela demanda nacional" (SUDAM, 1976).

Em síntese, a Amazônia transformava-se no sustentáculo da manutenção do desenvolvimento nacional e, na medida em que a mineração industrial ${ }^{3}$ evidenciava-se como o setor mais dinâmico para desempenhar esse papel de captador e gerador de divisas externas essenciais para o país, a Amazônia tornou-se o espaço geográfico por excelência para abrigar esse importante segmento industrial.

Os instrumentos de ação previstos pelo governo para a execução dessa estratégia eram fundamentalmente a realização de obras de infraestrutura e a concessão de incentivos fiscais e financeiros e de créditos

\footnotetext{
${ }^{3}$ De acordo com o II PND/II PDA, existiam vantagens comparativas na região para a exploração industrial de minério de ferro, manganês, bauxita, calcário, cassiterita, caulim e sal-gema. O segmento mineral concebido nos Pólos Agrominerais incluía a exploração de cassiterita e ilmenita (em Rondônia), bauxita (em Trombetas, Pará), minério de ferro (em Carajás, Pará) e manganês (no Amapá).
} 
diversos, assim como as transferências de recursos da União para a região, o que será analisado mais adiante. Paralelamente a isso, o governo apoiou e fomentou a participação (isolada ou associada) de empresas de capital nacional na viabilização dos empreendimentos do setor mineral. É nesse cenário que se destaca a importante participação da Companhia Vale do Rio Doce (CVRD) no desenvolvimento da mineração industrial na Amazônia.

Assim, durante a vigência do II PND/II PDA, foi efetivada a construção da UHE Tucuruí - planejada para fornecer energia elétrica subsidiada ao complexo produtivo do alumínio, que seria formado pela ALBRÁS, pela ALUNORTE e pela ALUMAR, e, de forma complementar, ao abastecimento de Belém e do Centro-Sul do país - e da ALBRÁS, da Mineração Rio do Norte e do Projeto Ferro Carajás.

A participação decisiva de outro importante condicionante estruturador da mineração na Amazônia - a concessão de incentivos fiscais e financeiros - ocorreu com a eclosão do segundo choque dos preços do petróleo no mercado internacional, entre 1978 e 1979. A economia brasileira sofreu um novo impacto e agora de forma mais profunda, em razão não somente do agudizamento da crise cambial e da manutenção de elevados déficits na balança comercial, mas também da evidente incapacidade financeira do Estado brasileiro para manter o padrão de desenvolvimento até então vigente.

Isso fez com que a Amazônia assumisse uma importância ainda maior enquanto geradora e captadora de divisas externas, levando o III PND (concebido nessa época) a reforçar ainda mais as estratégias e os objetivos previstos para a região no II PND. Em função disso, o governo ampliou ainda mais a sua atuação na região, criando, conseqüentemente, um novo programa de desenvolvimento regional, o Programa Grande Carajás (PGC) ${ }^{4}$. Esse programa continha um regime especial de concessão de incentivos fiscais, creditícios e outros, voltados não somente para os empreendimentos produtivos localizados na sua área de atuação geográfica, mas também para os da infra-estrutura física necessária à viabilização econômica desses empreendimentos produtivos, sobretudo os do ramo mineral.

O PGC passou a atuar de forma paralela a outros órgãos de desenvolvimento regional existentes na região, contribuindo assim para ampliar o leque de incentivos fiscais e financeiros previstos e garantidos para atrair os investimentos necessários ao cumprimento do papel estratégico que a região passou a assumir na economia nacional. De fato, na medida em que esse programa, de forma complementar, também ofereceu apoio financeiro aos projetos de pesquisa, prospecção, beneficiamento e extração mineral, assim como à industrialização desse

\footnotetext{
${ }^{4}$ O PGC foi criado pelo Decreto-Lei n. ${ }^{\circ} 1.813$, de 24 de novembro de 1980.
} 
segmento produtivo, a Amazônia tornou-se, do ponto de vista empresarial, atrativa para o desenvolvimento da indústria mineral e, do ponto de vista governamental, o espaço privilegiado para captação (empreendimentos com financiamento em moeda estrangeira), geração (exportações) e economia de divisas (substituição de importações).

Com esse último condicionante, associado aos demais já evidenciados, consolidou-se a estruturação da mineração industrial na região, assentada, portanto, nos empreendimentos industriais de exploração e de beneficiamento primário de minérios que se estabeleceram principalmente no Pará, na sua grande maioria, no período que vai do final dos anos 70 ao final dos anos 80. Isso posto, essa realidade distinguiu-se da dos anos 50 com o manganês do Amapá, sobretudo porque naquele caso inexistia qualquer benefício fiscal ou estratégia de desenvolvimento regional em operação na Amazônia.

\section{BENEFÍCIOS FISCAIS E FINANCEIROS CONCEDIDOS ÀS EMPRESAS DE MINERAÇÃO NA AMAZÔNIA}

A concessão de incentivos fiscais e financeiros foi um fator indispensável à consolidação da indústria de mineração na região. As ações desencadeadas pelo governo federal como parte da estratégia de desenvolvimento regional, no plano global, e as direcionadas para o desenvolvimento do setor mineral na região, no plano específico, voltaram-se em grande medida para essa questão.

Os incentivos sempre foram vistos como necessários à redução dos custos de implantação desses empreendimentos em uma região periférica, e a sua concessão permitiria (como permitiu) a compatibilização dos interesses do governo brasileiro em fomentar indústrias desse ramo produtivo na região com os interesses do capital estrangeiro em viabilizar a exploração dos bens minerais existentes em abundância na região. Isso ganhou mais importância localmente quando se associaram a essa estratégia os governos dos Estados do Pará e do Maranhão, induzidos pela política do governo federal.

Nas décadas de 1970 e de 1980, os incentivos concedidos procuraram fomentar e viabilizar a implantação de empreendimentos industriais; para tanto procuraram dar a esses empreendimentos um tratamento especial, do qual se beneficiaram na sua totalidade os empreendimentos minerais.

Os incentivos concedidos a esse setor e por ele apropriados tiveram tiveram diversas origens, mas basicamente se atendo aos concedidos pela SUDAM (isenção e redução do IR e adicionais não restituíveis; isenção e redução do II e do IPI sobre bens de capital importados; colaboração financeira do FINAM; além de outras fontes de recursos), pelo PGC (isenção do IR por 10 anos; isenção ou redução do II e do IPI 
incidentes sobre bens de capital sem similar nacional; e apoio financeiro para projetos de pesquisa, prospecção beneficiamento e extração de minérios), pela Comissão para Concessão de Benefícios Fiscais e Programas Especiais de Exportação - BEFIEX (isenção do II e do IPI sobre produtos industrializados à Albrás, no limite FOB de US\$ 150 milhões, até o final de 1995, para importar bens de capital, incluindo posteriormente matérias-primas e produtos intermediários). Pelo governo do Pará foi concedido diferimento no pagamento do ICMS a Alunorte por um período de 10 anos.

No final dessa primeira etapa, o governo paraense criou a Lei Estadual n. ${ }^{\circ}$ 5.530, de 13 de janeiro de 1989, que disciplinava o pagamento do ICMS no Estado e isentava de seu pagamento as operações de envio de produtos industrializados ao exterior, excluídos os semi-elaborados, mas o imposto seria não cumulativo, ou seja, haveria compensação pelo que fosse devido em cada operação. Essa iniciativa merece um destaque especial por dois motivos: primeiro, porque, como foi concebido, não permitia a concessão de benefício fiscal diretamente aos empreendimentos minerais na região, cuja produção é voltada exclusivamente para a exportação de produtos semi-elaborados - isso significa que a estratégia inicial do governo paraense era pressionar (sem sucesso) os empreendimentos minerais para ampliarem a verticalização produtiva do segmento no Estado; segundo, porque propiciou, com a sua reformulação nos anos 90, uma nova série de incentivos totalmente diferentes dos concedidos até então.

Além desses incentivos, merecem também destaque outras ações desenvolvidas pelo governo federal, por meio do PGC, que procuraram criar benefícios adicionais indiretos para os empreendimentos minerais na região: financiamento de obras de infra-estrutura de transporte (estrada de ferro Carajás-Ponta da Madeira, portos de Itaqui, Ponta de Madeira e Vila do Conde); financiamento de obras de infra-estrutura de energia (UHE Tucuruí); implantação e ampliação de núcleos urbanos (Marabá, Tucuruí, Carajás, Vila dos Cabanos); estabelecimentos de distritos industriais (Marabá, Parauapebas, Açailândia, Santa Inês, Rosário e São Luís).

Na década de 1990, aqui considerada como a segunda e atual etapa da política de concessão de incentivos fiscais e financeiros, a lógica que passou a marcar e a sustentar essa política não mais se preocupou com a necessidade de viabilizar a implantação de empreendimentos industriais (minerais) na região (no Pará e no Maranhão); antes procurou, por um lado, intensificar a produção industrial existente graças ao incentivo à ampliação da verticalização industrial do setor (mantendo a vertente exportadora) e, por outro lado, reduzir o custo de comercialização dos produtos colocados no mercado externo, de acordo com a política de redução "custo Brasil". 
Por sua vez, os incentivos concedidos nesse período não mais ficaram subordinados ou vinculados a uma estratégia de desenvolvimento regional, pois, além de os incentivos fiscais e financeiros concedidos no período anterior terem sido explicitamente reduzidos ou restringidos no início dos anos 90 pelo governo Collor ${ }^{5}$ (MENDES, 2000; CARVALHO, 1996), estava consolidando-se, em função da crise fiscal-financeira do Estado brasileiro, a desestruturação do aparato institucional que sustentava a política de desenvolvimento regional na Amazônia: o PGC foi extinto, e a SUDAM foi perdendo importância política e econômica, passando a ter cada vez menos recursos para financiar e promover o desenvolvimento da Amazônia (CARVALHO, 1996).

Agora, a estratégia de desenvolvimento da região passava a subordinar-se à lógica da integração competitiva que caracteriza a economia nacional, no bojo do processo de globalização econômica. Como a integração competitiva torna secundária a integração regional (ARAÚJO, 2000), passou a ocorrer uma substituição parcial da política regional por uma política de desenvolvimento regional do tipo federalista (AMARAL FILHO, 1995), isto é, na ausência de uma política explícita de desenvolvimento regional, fortaleceram-se as iniciativas locais desenvolvidas pelos estados federados.

Foi isso o que aconteceu no decorrer dos anos 90, principalmente no caso específico do Pará e do Maranhão, o que beneficiou em grande medida a mineração industrial. Na ausência ou na impossibilidade de surgimento de novos instrumentos de intervenção regional, as iniciativas relativas a benefícios fiscais e financeiros para o desenvolvimento do setor industrial (incluindo a mineração) processaram-se, a partir desse momento, no âmbito da legislação estadual, tendo como instrumento básico o ICMS.

Para o aprofundamento da análise desse período, entretanto, é imprescindível desdobrar esse processo em dois momentos: antes e depois da interferência do governo federal nas legislações estaduais, por meio da Lei Complementar n. ${ }^{\circ}$ 87, de 13 de setembro de 1996, mais conhecida como "Lei Kandir".

A Lei Complementar n. ${ }^{\circ}$ 87/96 foi aprovada no Congresso Nacional graças à iniciativa do governo federal, mas com o apoio das unidades federativas. Seu objetivo era constituir-se em um instrumento de política econômica destinado a reduzir o chamado "custo Brasil", na medida em que determinou a desoneração da cobrança do ICMS sobre as exportações brasileiras de produtos primários e produtos industrializados semielaborados ou serviços e sobre as operações interestaduais relativas à energia elétrica e ao petróleo, inclusive lubrificantes e combustíveis

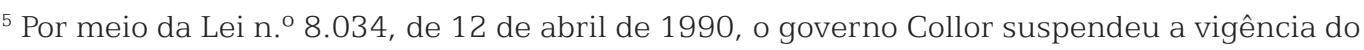
sistema de incentivos fiscais por tempo determinado, que voltou a vigorar no ano seguinte após pressão política das bancadas regionais. 
líquidos e gasosos derivados do petróleo, quando destinados à industrialização ou à comercialização .

\section{O caso do Pará}

Estando ainda em validade os efeitos da Lei Estadual n. ${ }^{\circ}$ 5.530/89, o governo paraense editou a Lei n. $^{\circ}$ 5.758, de 30 de agosto de 1993, que passou a assegurar o diferimento do pagamento do ICMS sobre operações relativas à extração, industrialização, circulação e comercialização de bauxita, alumina, alumínio e seus derivados, no território paraense, desde que não ocorressem saídas dos produtos para fora do território (mercado interno ou externo) ou dentro do Estado (consumidor final).

Assegurou com isso um tratamento tributário especial ao complexo industrial aluminífero, possibilitando com que o pagamento do ICMS passasse a ser cumulativo (diferentemente do que previa anteriormente a Lei Estadual $n^{\circ}$ 5.530/1989), ao mesmo tempo em que o pagamento deixaria de ser cobrado em cada operação e passaria a cobrado somente na última operação, ou seja, postergado para que a sua ocorrência se desse apenas na etapa final do processo produtivo local. Este tratamento tributário seria de 10 anos a contar da data de início da operação, sendo admitida prorrogação por igual período.

No início de 1996, por meio da Lei no 5.943/1996, o governo paraense adotou uma nova política de incentivos fiscais às atividades produtivas localizadas no seu território, concedendo: a) incentivos fiscais (inclusive para a mineração) sob a forma de isenção, redução da base cálculo, diferimento, crédito presumido ${ }^{8}$, e suspensão; b) incentivos financeiros, sob a forma de empréstimo, em valor correspondente a até 75\% do ICMS; c) incentivos de caráter infra-estrutural, para instalação ou relocalização de empreendimentos em pólos de desenvolvimento no Estado. Conforme será mostrado adiante, esta Lei propiciou tratamento tributário às empresas de mineração, sob a forma de crédito presumido, contribuindo para reduzir o custo operacional dessas empresas.

No segundo semestre de 1996, com a imposição da LC no 87/1996, deixou de existir o impedimento de isenção ou redução do ICMS para os produtos industriais semi-elaborados e, além disso, como foi consignado na nova legislação que essa isenção seria integral e não limitada ao

\footnotetext{
${ }^{6}$ A LC n. ${ }^{\circ}$ 87/96 tinha dois objetivos fundamentais: a) incentivar as exportações brasileiras a fim de melhorar o saldo do balanço de pagamentos; b) elevar os investimentos internos a fim de promover o crescimento econômico (PANDURO, 2001).

${ }^{7} \mathrm{O}$ diferimento é o instituto tributário pelo qual o momento do recolhimento do imposto incidente é postergado para evento futuro indicado em legislação tributária, sendo a responsabilidade do recolhimento do imposto transferida para o contribuinte que promover tal evento (vide art. 666 do Decreto Estadual n. ${ }^{\circ} 4.676$, de 18 de junho de 2001).

${ }^{8}$ O crédito presumido é um benefício fiscal utilizado somente no momento da apuração do imposto, no livro Registro de Apuração de ICMS, com vedação dos demais créditos fiscais, ou seja, não gera imposto na próxima etapa (vide Art. 12 do Decreto Estadual n 4.676/2001).
} 
valor agregado ocorrente na última operação (Panduro, 2001), deixou de ocorrer a incidência do imposto em todas as etapas da produção industrial, o que foi extremamente benéfico para a indústria mineral na medida em que a sua produção é direcionada na sua quase totalidade, para o mercado externo.

Em função dessas novas regras foi mantida a sistemática de apuração do imposto pelo confronto de débitos e créditos, garantido ao estabelecimento exportador a recuperação de eventuais saldos credores, por transferência para outro estabelecimento seu, no mesmo estado, ou de outro contribuinte, também localizado na mesma unidade federativa, ou de outro contribuinte localizado em outra unidade federativa (Panduro, 2001). Com isso, perdeu eficácia a cobrança do imposto sob a forma de diferimento no caso da produção mineral (Lei no 5.758/1993), visto que, ao chegar na última operação - exportação, entra em ação a Lei Kandir e isenta na sua totalidade o recolhimento do imposto. Continuar a cobrar o imposto em cada operação seria gerar um débito antecipado para o Estado pois, no momento da isenção do imposto, será garantido ao estabelecimento exportador o direito à obtenção desse crédito. Em resumo, não se constitui em um bom negócio para o Estado continuar recolhendo o imposto, portanto, nada mais a fazer senão garantir a eficácia da lei - isentar o recolhimento do ICMS para a exportação.

Um outro benefício que as indústrias de mineração na região passaram a usufruir por conta dessa lei, diz respeito à isenção do recolhimento do ICMS sobre o consumo de energia elétrica e de combustíveis. O Estado deixou de arrecadar o ICMS que antes era gerado pela comercialização de energia elétrica oriunda da UHE Tucuruí. Portanto, mais um ônus transferido para o ente federativo estadual.

Por conta disso, passou também a não ser um bom negócio quando o insumo - minério, na sua forma bruta ou semi-beneficiada, ou energia elétrica - utilizado na indústria mineral provém de outra unidade federativa pois, nesse caso, o Estado recebedor ressarcirá ao estabelecimento exportador o valor do imposto que lhe foi cobrado no Estado de origem do produto (transação interestadual). Esta situação afeta tanto o Pará, em relação ao imposto recolhido no Amapá por conta do minério de caulim oriundo da Mina do Felipe (em Mazagão) e destinado à unidade de beneficiamento da Cadam no território paraense, quanto o Maranhão, em relação ao imposto recolhido no Pará por conta dos insumos minerais e da energia elétrica destinadas ao beneficiamento industrial no Maranhão.

A partir de então, ex post a esse fato, o governo paraense procedeu a adequação de sua legislação tributária. Só que isto não ocorreu de imediato, sendo apenas atendido o princípio da desoneração da cobrança

${ }^{9}$ A LC no 87/1996 também determinou o aproveitamento dos créditos das aquisições de todo material de uso e consumo a partir de 1988, sendo postergada a sua utilização para janeiro/ 2000 (LC n 92/1997) e, posteriormente, para janeiro/2003 (LC nº 99/1999). 
do ICMS no momento da exportação, conforme determina a LC $\mathrm{n}^{\circ}$ 87/ 1996. Portanto, não houve de imediato a edição de qualquer nova legislação estadual. Afora esse princípio, estava ainda em validade os efeitos da Lei $n^{\circ}$ 5.530/1989, no que concerne a não cumulatividade da cobrança desse imposto aos bens semi-beneficiados, incluindo os bens minerais (com exceção da produção aluminífera - Lei no 5.758/1993).

Esta situação somente se modificou em meados do ano 2000, quando o governo estadual percebeu que o crédito que a CVRD tinha, em função do princípio da recuperação de saldos credores do recolhimento do ICMS, era extremamente elevado e, portanto, devia ser devolvido a essa empresa. Para que isto não onerasse as finanças estaduais naquele ano, o governo confrontou esse crédito com alguns débitos da empresa referente a multas diversas, o que resultou numa amortização parcial do valor que deveria ser pago pelo Estado.

Mas, com vistas a evitar a repetir essa cena nos anos posteriores, o governo do Pará editou a Lei no 6.307/2000, que assegurou, a partir de então, o diferimento do pagamento do ICMS sobre operações relativas à extração, circulação, comercialização, operações de serviço de transporte de bauxita, alumina, alumínio e seus derivados, e manganês e minério de ferro, no território paraense. Isto é, estendeu os efeitos da Lei no 5.758/1993 para a produção de ferro e manganês, contemplando assim toda a produção mineral realizada pela CVRD no Pará (até então).

O mais curioso é que, ao ampliar a abrangência da Lei $n^{\circ}$ 5.758/ 1993, a nova Lei não limitou o prazo de concessão desse tratamento tributário por apenas 10 anos (prorrogáveis por mais 10 anos), conforme disciplinava a legislação anterior, mas ampliou-o para 15 anos, a partir de julho/2000. Dessa forma, no caso específico do pólo aluminífero, que tinha sido beneficiado anteriormente, o seu prazo para usufruto desse benefício passava a ser de 1993 a 2015, ou seja, de 22 anos $^{10}$. Além disso, essa nova Lei beneficiou também a CVRD nas operações relativas às aquisições interestaduais de bens destinados ao ativo imobilizado, importações do exterior de insumos e de bens destinados ao ativo imobilizado, e aquisições internas de energia elétrica.

Para completar todo o circuito que envolve a produção da CVRD no Pará, o governo estadual passou também a beneficiar as empresas locais que comercializam seus produtos com aquela empresa de mineração, em seus diversos projetos industriais, ao estender também a concessão do diferido no pagamento do ICMS no fornecimento, em operações internas, de bens para integração ao ativo imobilizado e de bens de uso e consumo destinados aos estabelecimentos extratores e

\footnotetext{
${ }^{10} \mathrm{Na}$ verdade, a idéia inicial era reproduzir o período máximo de 20 anos concebido na legislação anterior, só que entre o momento de concepção e o momento de aprovação da nova Lei levou exatamente dois anos, e isto acabou por beneficiar a indústria aluminífera em mais dois anos de benefícios.
} 
industriais de bauxita, alumina, alumínio e seus derivados, manganês e minério de ferro, no território paraense (Decreto $n^{\circ} 4.401 / 2000$ ).

Completou-se assim o circuito de mudanças na legislação estadual em decorrência da aplicação da Lei Kandir, sujeitando-se o Estado a um papel secundário nesse processo, e validando a importância estratégica da mineração industrial (mais precisamente da CVRD) no desenvolvimento da economia paraense à base de novos incentivos fiscais.

\section{O caso do Maranhão}

Nos anos 1990, o desenvolvimento industrial no Maranhão apoiouse, inicialmente, no Programa de Apoio ao Desenvolvimento Industrial (PRODEIN), criado pela Lei n. ${ }^{\circ}$ 5.261, de 12 de novembro de 1991, que concedia financiamentos às empresas industriais que se instalassem nesse Estado. Mas, na passagem da primeira para a segunda metade da década de 90, o governo maranhense apresentou um novo modelo de suporte ao desenvolvimento do setor industrial, agora com base na utilização dos recursos do ICMS. Por meio da Lei n. ${ }^{\circ}$ 6.429, de 20 de setembro de 1995, criou o Sistema de Apoio à Indústria e ao Comércio Exterior (SINCOEX), com o objetivo de incentivar o desenvolvimento das atividades industriais e agroindustriais e promover as atividades de comércio exterior no Estado, mediante o financiamento de até $75 \%$ do produto resultante do recolhimento do ICMS devido ${ }^{11}$. O usufruto desse benefício seria, inicialmente, de 5 anos, mas, logo em seguida, o prazo foi estendido para 10 anos (Lei n. ${ }^{\circ}$ 6.514, de 4 de dezembro de 1995).

Com a edição da Lei Complementar n. ${ }^{\circ}$ 87/96, o governo maranhense viu-se obrigado a conceber uma nova disposição legal sobre o ICMS no seu território. Por meio da Lei Estadual n. ${ }^{0}$ 6.866, de 5 de dezembro de 1996, instituiu uma nova legislação sobre esse tributo que, entre outras determinações, estabeleceu: a) isenção da incidência do ICMS para as operações de prestações que destinem ao exterior mercadorias, inclusive produtos primários e produtos industrializados semi-elaborados, ou serviços, e, ainda, as operações interestaduais relativas à energia elétrica e ao petróleo, quando destinados à industrialização ou à comercialização; b) direito ao crédito acumulado nas operações de exportação, decorrentes de eventual saldo credor; c) possibilidade de transferência do crédito acumulado para qualquer estabelecimento da mesma empresa situado no Estado ou para outros contribuintes estabelecidos no Estado.

A partir de então, o governo estadual deixou de recolher o ICMS devido pertinente à produção aluminífera (ALUMAR) e à produção siderúrgica do seu Estado, ambas destinadas à exportação, como ocorre no Pará. Por sua vez, passou a ressarcir os empreendimentos minerais exportadores pelos créditos decorrentes do ICMS cobrado no Pará, visto

${ }^{11}$ Se o empreendimento se localizasse em município que tivesse aderido ao SINCOEX, o financiamento poderia ser de até 100\% do ICMS devido. 
que os insumos minerais e a energia elétrica consumidos por esses empreendimentos provêm do Pará.

$\mathrm{Na}$ seqüência dos ajustes na legislação, o governo estadual concedeu o diferimento no pagamento do ICMS para as operações e prestações de serviços das usinas produtoras de pellets de minério de ferro e seus concentrados que viessem a implantar-se no Estado e em operação até dezembro de 2002 (Lei n. ${ }^{\circ}$ 7.323, de 26 de outubro de 1998). Essa concessão passou a ocorrer nas aquisições internas de matéria-prima, material de embalagem, bens destinados ao ativo permanente, material de uso ou consumo, produtos intermediários, energia elétrica, gás natural e serviços de transporte e comunicações. Além disso, passou a ser aplicado o diferencial de alíquota nas aquisições de bens destinados ao ativo permanente, materiais de uso e consumo, bem como no serviço de transporte, deixando de ocorrer esse benefício na saída interna do produto acabado. Esse tratamento fiscal foi concedido pelo prazo de 20 anos, a partir da implantação da usina de pelotização, com possibilidade de prorrogação por mais 10 anos.

Mas, logo em seguida, pelo Decreto n. ${ }^{\circ} 16.645$, de 10 de dezembro de 1998, o governo maranhense passou também a conceder a transferência (para terceiros) de saldo credor do ICMS (reconhecimento do crédito acumulado do imposto) nas operações de comercialização e prestação de serviços de transporte de pellets, minério de ferro e seus concentrados $^{12}$. Em outras palavras, a usina de pelotização deixa de pagar o ICMS devido, transferindo essa obrigação a terceiros, no caso, as usinas siderúrgicas. Entretanto, como elas estão isentas desse pagamento, por conta dos efeitos da Lei Kandir, o imposto deixa de ser recolhido em todas as etapas do beneficiamento da produção mineral no Estado. Além disso, o governo maranhense também criou a possibilidade de não recolher esse imposto quando aqueles produtos se destinarem a outros estados, visto que, mediante Protocolo interestadual, a cobrança do imposto pode ser transferida para outras unidades da Federação.

Do mesmo modo, o governo maranhense passou a conceder também ao estabelecimento industrial exportador que beneficie finos de minério de ferro para adequação granulométrica ao uso no processo siderúrgico a possibilidade de transferir o seu saldo credor, existente a partir de $1 .^{\circ}$ de abril de 2000, a qualquer título, a outro contribuinte do imposto localizado no Estado, para pagamento do ICMS (Decreto n. ${ }^{\circ} 17.275$, de 25 de abril de 2000) ${ }^{13}$. Isso significa que, efetivamente, em vez de ressarcir o empreendimento exportador pelos créditos

\footnotetext{
${ }^{12}$ Esse Decreto permitiu inclusive que o saldo credor do ICMS existente a partir de $1 .^{\circ}$ de outubro de 1998 fosse utilizado como compensação com débito normal do mesmo imposto, pagamento de débito com esse imposto e outros (novas situações de compensação foram incluídas a partir dos Decretos n. ${ }^{\circ}$ 17.546, de 29 de setembro de 2000, e n. ${ }^{\circ} 17.679$, de 30 de novembro de 2000).

${ }^{13}$ Condicionante mantido pelo Decreto Estadual n. ${ }^{\circ} 17.765$, de 8 de fevereiro de 2001.
} 
acumulados, o Estado deixa de receber o imposto devido de um outro contribuinte fiscal, no mesmo montante do crédito pertencente àquele empreendimento, por meio de um sistema de compensação. Não há receita auferida, mas em contrapartida o Estado não tem despesa realizada. Em suma, sem ganhos e sem perdas.

No mesmo ano, em outubro de 2000, o governo maranhense precisou que esse sistema de compensação poderia ocorrer para pagamento de débito relativo ao ICMS e seus acréscimos legais, inscrito em dívida ativa, para pagamento do ICMS incidente na importação de bens para o ativo permanente do estabelecimento e para pagamento do ICMS incidente na entrada de mercadoria oriunda de outra unidade da federação destinada ao ativo permanente (Decreto n. ${ }^{\circ}$ 17.548/00). E, por meio da Lei Estadual n. ${ }^{0}$ 7.568, de 7 de dezembro de 2000, determinou que essa forma de compensação, concebida de forma genérica desde a Lei Estadual n. ${ }^{\circ}$ 6.866/96, relativa aos saldos credores existentes em 31 de dezembro de 1999 e ainda compensados ou transferidos até a data da entrada em vigor da Lei Complementar $\mathrm{n} .^{\circ}$ 102, de 11 de julho de 2000, ocorresse de forma parcelada.

Com essas reformulações na legislação estadual, o Maranhão passou a ter uma situação fiscal semelhante à do Pará, isentando da incidência do ICMS todas as etapas vinculadas ou relacionadas à produção, à comercialização e à exportação da indústria mineral em seu território. Se, do ponto de vista político, é um bom negócio ter um empreendimento produtivo desse tipo em seu território (principalmente quando há disputa interestadual pela localização do empreendimento), do ponto de vista tributário, é um mau negócio, pois o Estado, além de não poder arrecadar os tributos que lhe competem, ainda tem de dispor de parte da sua receita para ressarcir o empreendimento pelos créditos acumulados.

Por conta disso, para os técnicos da Gerência de Estado da Receita Estadual do Maranhão (GERE), não será um bom negócio a instalação, no Maranhão, do pólo siderúrgico para verticalização do minério de ferro de Carajás (produção estimada de 3,7 milhões de t/ano de placas de aço), da CVRD, pois isso aumentará ainda mais a ocorrência de saldos credores (visto que o insumo mineral e a energia elétrica serão oriundos do Pará, e esse Estado pretende cobrar o ICMS devido por essa operação interestadual), os quais deverão ser ressarcidos pelo Estado. Portanto, se, por um lado, esse projeto poderá gerar mais empregos (em termos nominais), por outro lado, contribuirá para diminuir a receita estadual do Maranhão.

\section{O caso do Amapá}

Desde o início dos anos 90, a atenção do Amapá em termos da legislação fiscal tem-se concentrado na Área de Livre Comércio de Macapá e Santana (ALCMS), principal suporte do dinamismo econômico 
local, sobretudo após o término da exploração do minério de manganês da Serra do Navio.

Por conta disso, o governo estadual concedeu a partir de então (Lei n. ${ }^{\circ} 18$, de 26 de junho de 1992) crédito fiscal presumido nas entradas de mercadorias industrializadas na Área de Livre Comércio, igual ao montante que teria sido pago na origem em outras unidades da Federação.

Em fins de 1993 e no decorrer de 1994, o governo estadual editou diversos decretos ${ }^{14}$ que, por força de convênio com a União, permitiam redução da base de cálculo do ICMS na exportação de alumínio e seus derivados, de pasta química de madeira para dissolução, de minério de ferro e pellets, e de produtos siderúrgicos. Todavia, isso em nada repercutiu na arrecadação tributária local, dada a inexistência do beneficiamento desses produtos no Estado. Já não foi o caso da exportação do cavaco de madeira que, produzido pela Amapá Florestal e Celulose SA (Amcel), mereceu tratamento especial com a redução da base de cálculo do ICMS em 50\%, nas operações realizadas até agosto de 1994, e em $20 \%$ nas operações realizadas no período de $1 .^{\circ}$ de setembro a 31 de dezembro de 1994 (Decreto n. ${ }^{\circ} 1.521$, de 5 de maio de 1994) ${ }^{15}$.

No final de 1995, quando da aprovação do Regulamento do ICMS (Decreto n. ${ }^{\circ} 3.174$, de 20 de novembro de 1995), ficou determinado que quaisquer produtos industrializados exportados teriam isenção na incidência desse imposto, com exceção dos produtos semi-elaborados. Afinal, assim como em outras regiões, o importante era incentivar o maior grau de beneficiamento industrial localmente. Contudo, com a vigência da Lei Complementar n. ${ }^{\circ}$ 87/96, essa restrição desapareceu da legislação fiscal do Amapá. Pelo Decreto n. ${ }^{\circ}$ 2.950, de 9 de maio de 1997, a isenção do ICMS também se estendeu aos produtos primários e semi-elaborados exportados, assim como aos serviços e combustíveis e energia elétrica destinados à industrialização ou à comercialização. Essa mesma determinação foi inserida no novo Regulamento do ICMS, aprovado pelo Decreto n. ${ }^{\circ}$ 2.269, de 24 de julho de 1998.

Como o Amapá não registrou exportação oriunda da indústria mineral após esse período, a não ser parte da produção de caulim oriunda da Caulim da Amazônia SA (CADAM) (cujos registros contábeis têm sido deficientes por parte da Secretaria da Fazenda do Amapá), o Estado não tem sentido necessidade de proceder a novas alterações na sua legislação vigente. Na verdade, as alterações mais recentes têm-se aplicado basicamente aos casos de produtos primários ou semielaborados, como a madeira, cavacos e outros.

\footnotetext{
${ }^{14}$ Decretos n. ${ }^{\circ} 2.199 / 93$, n. ${ }^{\circ} 094 / 94$, n. ${ }^{\circ} 2.487 / 94$, n. ${ }^{\circ} 4.500 / 94$ e n. ${ }^{\circ}$ 5.366/94.

${ }^{15}$ Posteriormente foi reduzido para $69,2 \%$ do valor do imposto devido, conforme Decretos $\mathrm{n}{ }^{\circ}$ 2.149/95, n. ${ }^{\circ} 2.598 / 95$ e n. ${ }^{\circ} 1.538 / 96$.
} 


\section{IMPACTOS DECORRENTES DOS BENEFÍCIOS TRIBUTÁRIOS CONCEDIDOS ÀS EMPRESAS DE MINERAÇÃO NA AMAZÔNIA}

Em tese, a isenção ou a renúncia de um tributo diminui a arrecadação fiscal do ente federativo que a concede. De acordo com o princípio que tem fundamentado a política de desenvolvimento regional no país, a concessão desse tratamento tributário é imprescindível para a atração de empreendimentos produtivos para a região; no momento em que esses empreendimentos iniciarem a sua produção, haverá um novo tipo de incidência tributária, da qual diretamente se beneficiará o ente federativo subnacional, no caso, os governos estaduais (e, por tabela, as instâncias municipais).

Na verdade, essa tese refere-se a uma determinada situação de isenção tributária; no caso brasileiro, acabou também por referir-se a um determinado momento histórico que se iniciou em meados dos anos 60 e perdurou até meados dos anos 80 . Quando muda o objetivo que sustenta ideologicamente o princípio da isenção, mudam os seus resultados. E foi isso o que ocorreu na região no que diz respeito à arrecadação tributária decorrente da produção oriunda da mineração industrial.

Quando o princípio da isenção visava garantir que a região se tornasse por excelência a captadora ou geradora de divisas externas para o país - e por conta disso as isenções tributárias ocorriam nos tributos pertinentes à União -, o Pará, o Maranhão e o Amapá não sofreram impacto negativo na sua arrecadação tributária; ao contrário, elevaram a sua arrecadação por conta da dinamização da produção local com a implantação dos empreendimentos minerais em seu território. Porém, quando o princípio da isenção passou a ser o da redução do chamado "custo Brasil" - e, conseqüentemente, as isenções tributárias deveriam também incidir nos tributos estaduais, no caso, no ICMS, que constitui a principal fonte de arrecadação dos estados -, essas unidades federativas sofreram uma redução na sua arrecadação própria, visto que, após a vigência da LC n. ${ }^{\circ}$ 87/96 (e suas alterações), os produtos primários e os semibeneficiados voltados para a exportação deixaram de ser tributados com relação ao ICMS.

Isso posto, e em consonância com os objetivos desta análise, procurarse-á evidenciar os impactos dessa mudança de estratégia governamental basicamente nos benefícios tributários concedidos à mineração industrial desses estados, buscando-se verificar a) a relação entre os resultados alcançados e as metas contidas na LC n. ${ }^{\circ} 87 / 96$, b) o impacto na receita estadual e c) o impacto na arrecadação dos entes municipais.

\subsection{Na balança comercial brasileira}

Quando a Lei Kandir foi concebida, o governo federal procurou não alterar a política cambial então praticada no país, que garantia a 
paridade do real em relação ao dólar americano (essa política somente foi alterada no início de 1999). Portanto, como forma de melhorar o saldo da balança comercial brasileira, a única saída encontrada foi incentivar as exportações brasileiras. Ao lado disso, era imprescindível que se elevassem os investimentos internos a fim de promover o crescimento econômico. Assim sendo, a LC n. ${ }^{\circ} 87 / 96$ procurava em seu discurso contemplar uma situação hipotética que resultaria, por um lado, numa expansão da produção voltada para o mercado externo e, por outro lado, numa ampliação dos setores industriais no país. Portanto, poderse-ia imaginar que os incentivos concedidos promoveriam o aumento da produção dos bens minerais semibeneficiados destinados à exportação, ao mesmo tempo que suscitariam a implantação de novos empreendimentos minerais na região.

\section{O caso do Pará}

Os objetivos da Lei Kandir não foram alcançados no Pará. Não se implantou nenhum outro empreendimento industrial do ramo mineral no Estado, nem tampouco houve expansão significativa na produção mineral voltada para a exportação. Ao contrário, em alguns casos houve uma retração na produção.

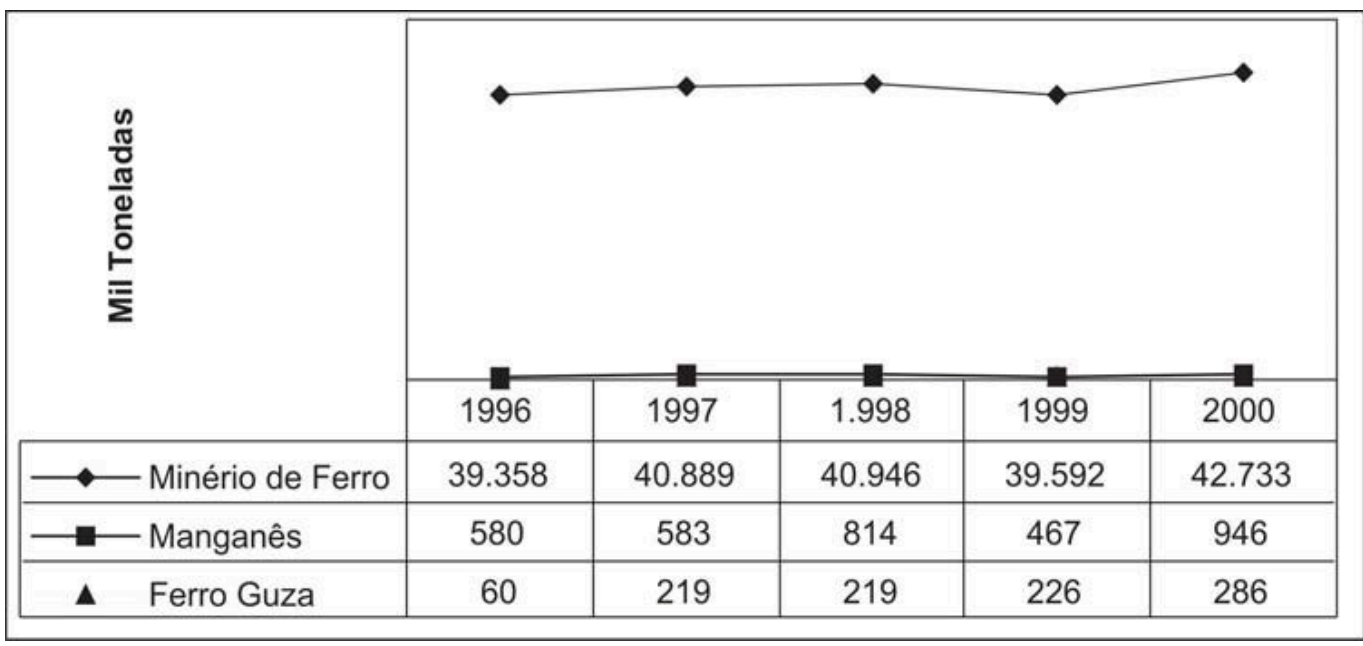

Gráfico 1: Pará: exportação de produtos minerais (minério de ferro, manganês e ferro-gusa).

Fonte: Fonte: MDIC-ALICEWEB 2002.

A produção de minério de ferro, que se tem expandido a cada ano, passou de 40 milhões de toneladas para 42 milhões de toneladas entre 1997 e 2000, ou seja, evoluiu cerca de 5\% nesse período; a produção de manganês passou de 583 mil toneladas para 946 mil toneladas no período, evoluindo 62\%, enquanto, entre 1996 e 1997 (antes da aplicação da Lei Kandir) a produção tinha crescido apenas 1\%; a produção de ferro-gusa evoluiu de 219 mil toneladas para 286 mil toneladas (expansão de 30\%), enquanto, entre 1996 e 1997, 
o seu crescimento chegou a ser de quase 4 vezes (Gráfico 1). Pelo que se percebe, a desoneração do ICMS não incidiu ou (quase nada) influiu na expansão da produção desses minérios, tendo sido mais significativo o crescimento que vinha ocorrendo anteriormente à aplicação dessa Lei.

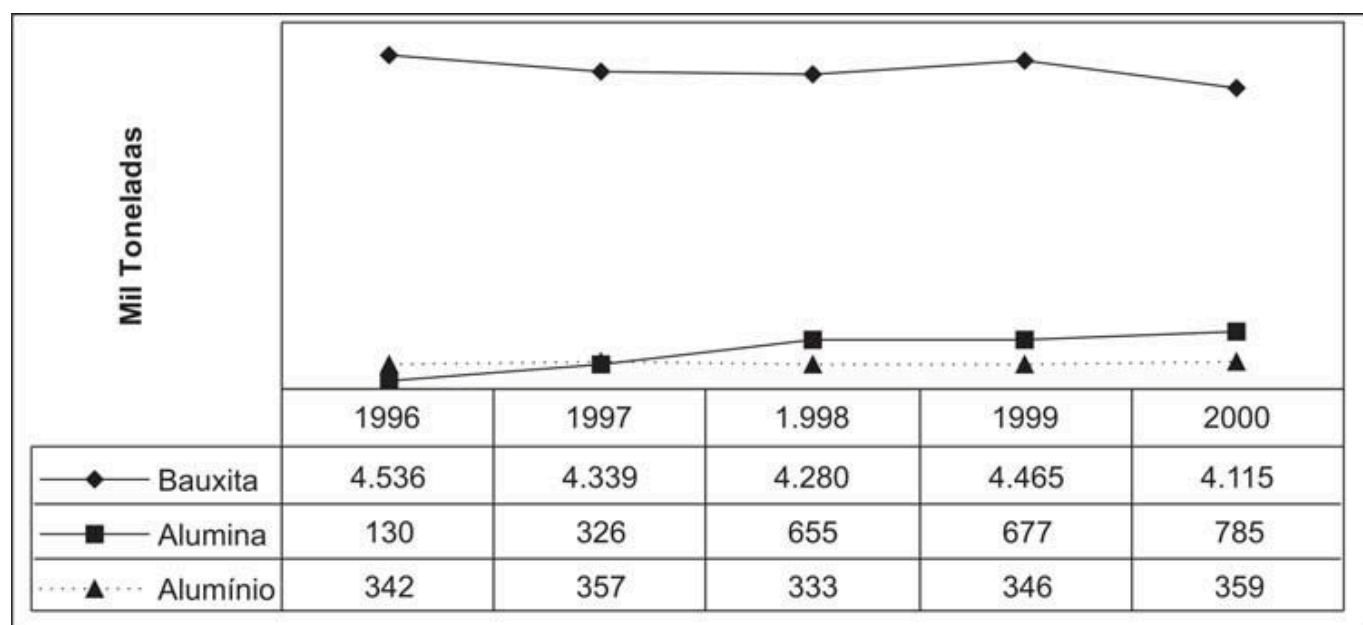

Gráfico 2: Pará: exportação de produtos minerais (bauxita, alumina e alumínio).

Fonte: Fonte: MDIC-ALICEWEB 2002.

A produção de caulim, que também é recente no Pará, evoluiu de 597 mil toneladas para 1,39 milhão de toneladas no período em análise (132\%). Por fim, a produção de silício retraiu-se, passando de 30 mil toneladas para 16 mil toneladas, o que representa um decréscimo de 47\% (Gráfico 3).

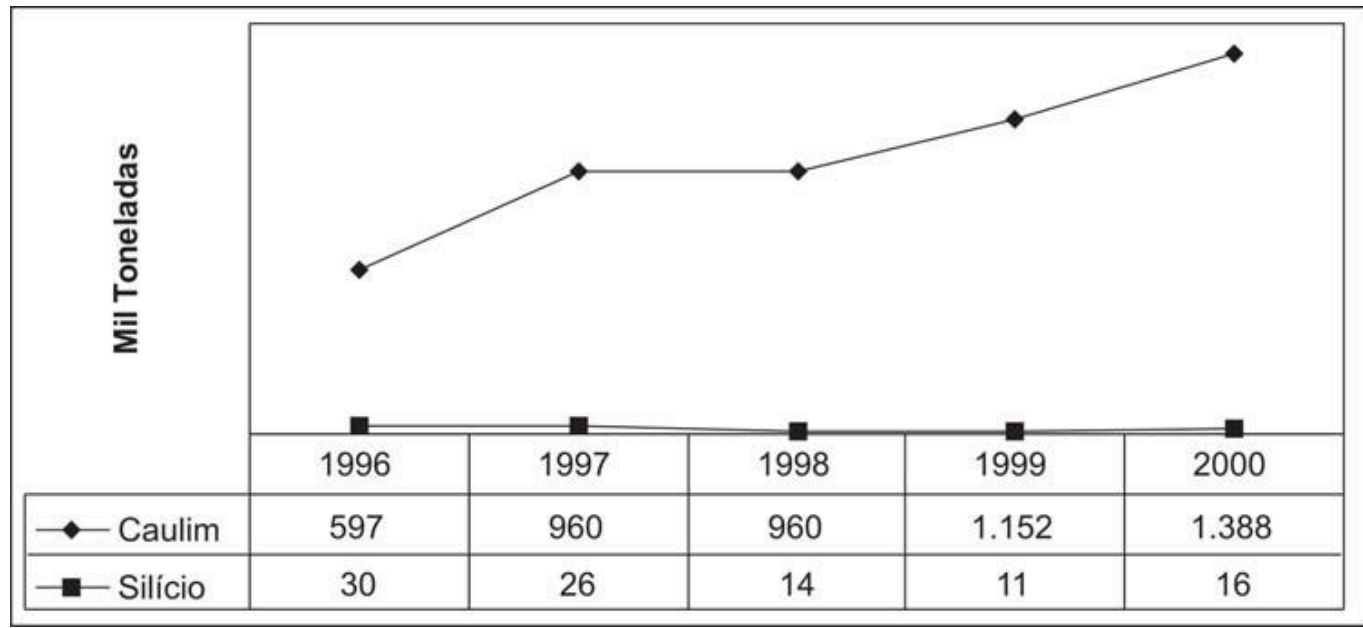

Gráfico 3: Pará: exportação de produtos minerais (caulim e silício). Fonte: Fonte: MDIC-ALICEWEB 2002.

Como se percebe, não houve uma influência direta da LC n. ${ }^{\circ}$ 87/96 na evolução da produção mineral no Pará, o que permite afirmar que 
os efeitos dessa Lei beneficiaram os empreendimentos minerais independentemente dos seus custos de produção e dos preços com que os seus produtos são comercializados no mercado internacional. É bom não esquecer que esses bens minerais semibeneficiados constituem-se em commodities, portanto, os seus preços são determinados no circuito do mercado mundial em função da interação de diversos fatores exógenos; logo, os efeitos imediatos estão muito mais na ampliação da lucratividade desses empreendimentos do que, evidentemente, na ampliação da produção em decorrência do rebaixamento dos custos de produção.

Independentemente dessa questão, o Pará tem ampliado a sua contribuição para a geração de saldos favoráveis na balança comercial brasileira, na medida em que o valor global das exportações é infinitamente superior ao valor global das importações do Estado. Aliás, pouco são os produtos consumidos diretamente pelo Estado do Pará no mercado internacional, limitando-se em grande parte a bens de capital utilizados pelos empreendimentos econômicos de grande porte. Dessa forma, analisando-se o período de 1990 a 2000, verifica-se que o saldo da balança comercial paraense foi sempre ascendente, tendo evoluído de US\$ 1,3 bilhão para US\$ 2,2 bilhões no período analisado (Gráfico 4).

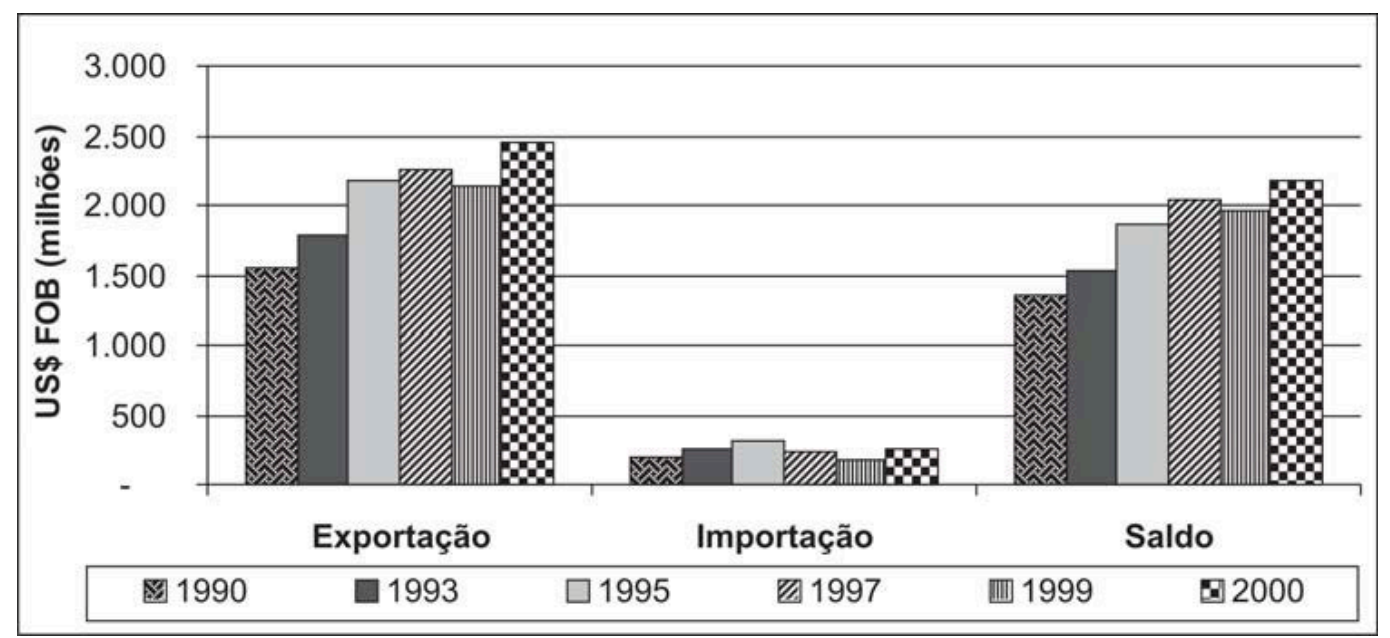

Gráfico 4: Balança comercial do Pará.

\section{O caso do Maranhão}

A exportação do Maranhão está assentada basicamente em produtos básicos e semimanufaturados. No início dos anos 90, esses dois conjuntos de produtos perfaziam 93\% da pauta de exportação, contra apenas $7 \%$ de produtos manufaturados. Ao longo da década, o percentual relativo aos produtos manufaturados foi se expandindo ( $9 \%$ em 1999 e 12\% em 2002), mas não impediu o predomínio dos primeiros (Gráfico 5). 


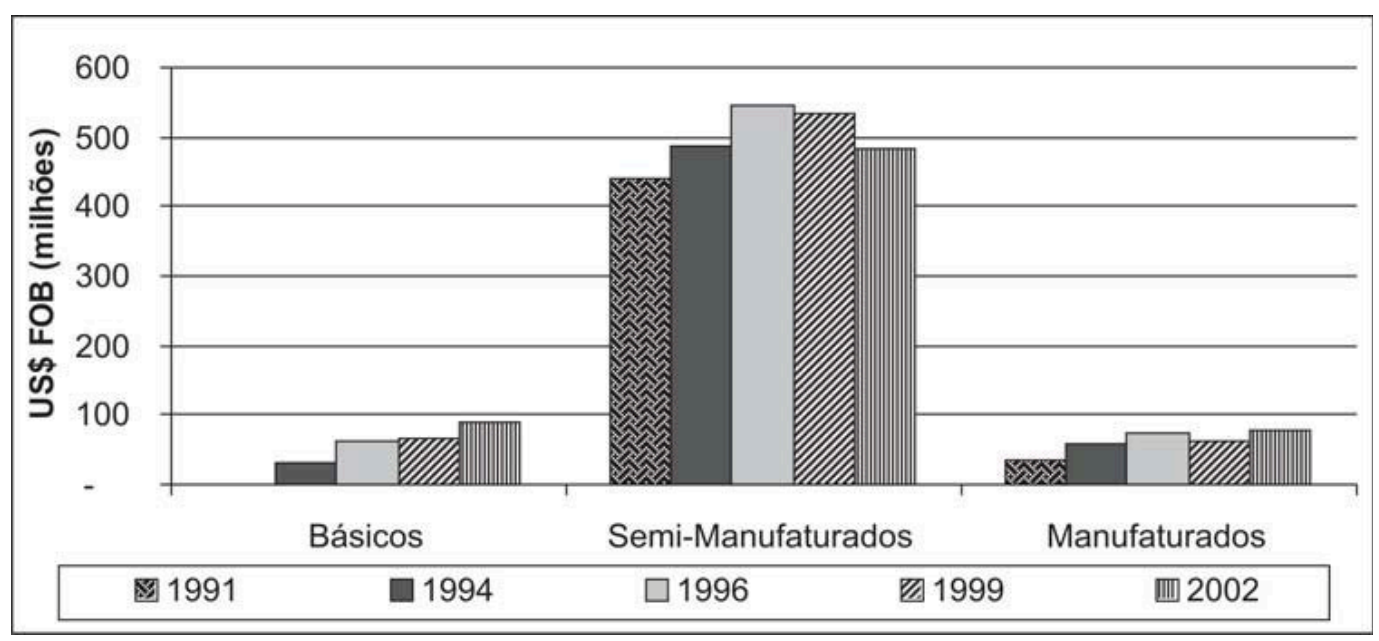

Gráfico 5: Maranhão: exportação de produtos.

Os produtos semimanufaturados predominam absolutamente na pauta de exportação do Maranhão. Seu crescimento foi maior na primeira metade dos anos 90, tendo diminuído a partir de 1997. O mesmo ocorre com os produtos básicos, que só conseguem recuperar o seu ímpeto de crescimento em 2002. À primeira vista, esse resultado destoa do que seria esperado pelos efeitos da Lei Kandir, pois essa legislação deveria contribuir para intensificar a produção que recebe desoneração de imposto. Entretanto, como o volume e os preços desses tipos de produtos são determinados não pela redução dos custos de produção nos países de origem, mas pela demanda do mercado internacional, a Lei Kandir em nada contribuiu para intensificar ou dinamizar a produção estadual, ainda que se considere a área da produção mineral.

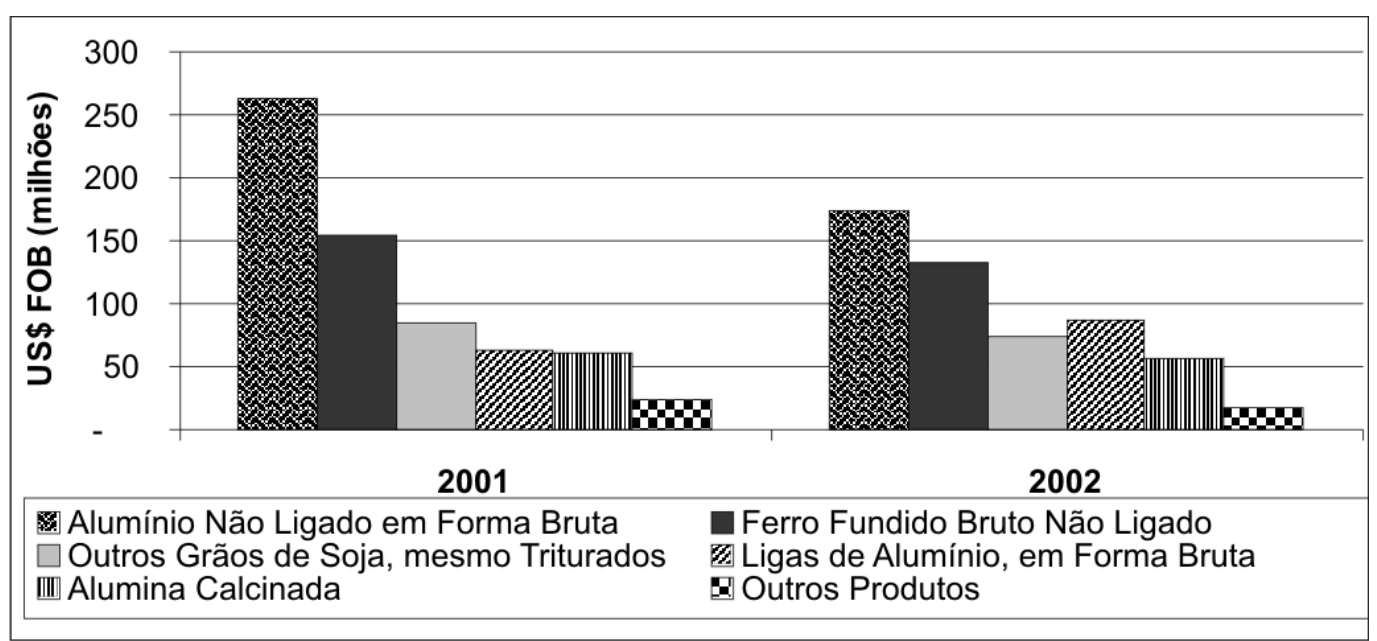

Gráfico 6: Maranhão: principais produtos exportados.

A produção mineral predomina de forma absoluta na pauta de exportação do Maranhão. De acordo com os dados apresentados no Gráfico 6, do total do que é exportado pelo Estado, 83\% referem-se a 
ferro fundido, alumina, ligas de alumínio e alumínio não ligado (com a liderança desse último). Essa participação percentual tem-se mantido, embora o volume exportado tenha caído entre 2001 e 2002.

Conseqüentemente, o impacto mais expressivo será, em um primeiro momento, a diminuição do saldo da balança comercial do Estado, já desde 1996, visto que o volume de importação realizada pelo Estado é permanentemente crescente, apresentando saltos qualitativos tanto em 1996 quanto em 2002, e, posteriormente, a ocorrência de saldos deficitários após 2000 (Gráfico 7).

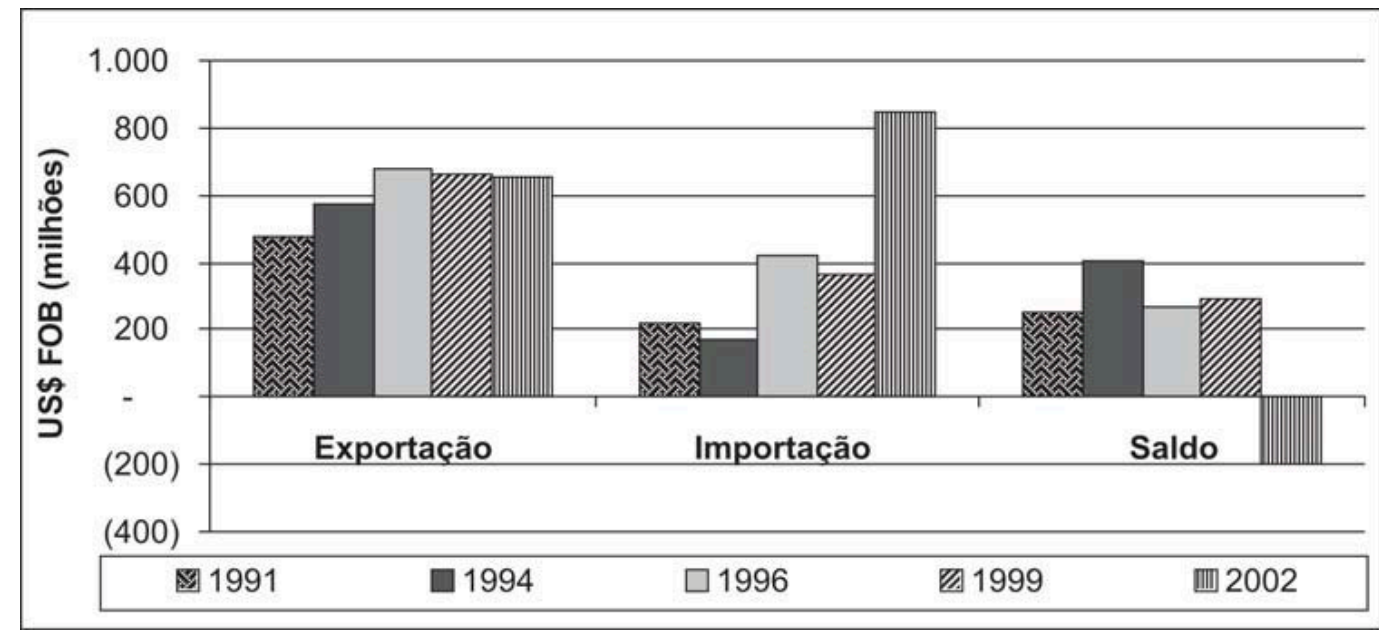

Gráfico 7: Balança comercial do Maranhão.

\section{O caso do Amapá}

A exportação do Amapá caracteriza-se por uma singularidade: até a primeira metade dos anos 90, a sua pauta de exportação era predominantemente liderada pelo minério de manganês, da Indústria e Comércio de Minérios SA (ICOMI). Mas, como as jazidas desse minério já se encontravam em estado de exaustão, a sua exploração vinha decrescendo nos últimos anos, tendo sido dado por encerrada em meados da década de 1990. A partir daí, essa hegemonia é assumida pela exportação de madeira, a partir da Amapá Florestal e Celulose SA, da Indústria Exportadora de Madeira (IMMA) e de outras empresas.

Essa realidade está refletida nos dados apresentados pelos Gráficos 8 e 9. Na primeira situação (Gráfico 8), verifica-se que, até meados dos anos 90, predominavam na pauta de exportação do Amapá produtos considerados como básicos (responsáveis por 86\% das exportações em 1991), porém, já em 1996 e nos anos posteriores, os produtos semimanufaturados assumem a liderança (em 1996 foi muito expressiva essa liderança, representando 60\% do total exportado pelo Estado). Em 2002, a liderança desses produtos é praticamente dividida com os produtos manufaturados, representando, em conjunto, $86 \%$ do total exportado. 


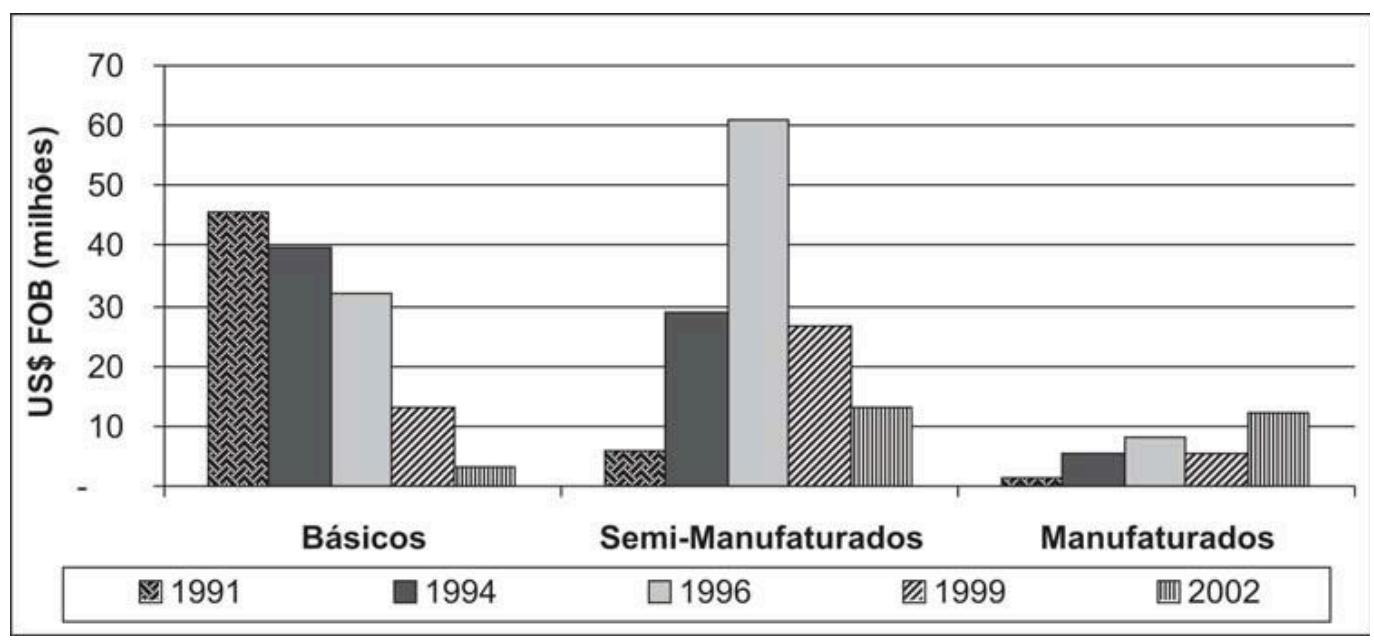

Gráfico 8: Amapá: exportação de produtos.

O Gráfico 9 mostra com evidência os principais produtos exportados pelo Amapá em 2001 e 2002. Constata-se que a madeira representa o equivalente a $75 \%$ da pauta de exportação estadual, mantendo-se nesse mesmo patamar mesmo quando há um decréscimo global no valor exportado pelo Estado entre um ano e outro. Os produtos minerais, sobretudo o minério de cobre, de nióbio e de manganês, têm sofrido redução no volume exportado, significando cada vez menos na pauta de exportação do Estado.

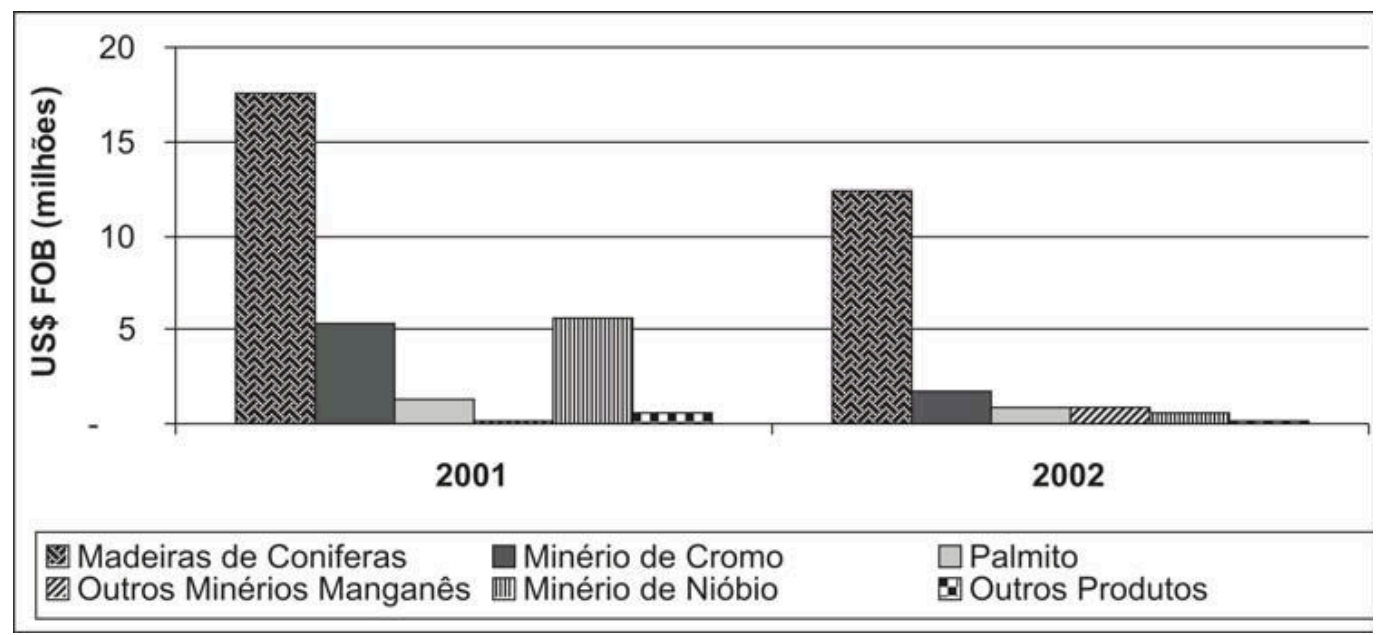

Gráfico 9: Amapá: principais produtos exportados.

Nos anos de 2001-2002 a madeira representou o equivalente a $75 \%$ da pauta dos principais produtos exportados, mantendo-se nesse mesmo patamar mesmo quando houve um decréscimo global no valor exportado pelo Estado entre um ano e outro. Os produtos minerais, com mais evidência o minério de cobre, de nióbio e de manganês, vêm sofrendo redução no seu volume exportado, significando cada vez menos na pauta do Estado. 
O resultado mais concreto é que não houve nenhum impacto favorável da Lei Kandir no Amapá. A evolução da exportação de madeira e de outros produtos (inclusive dos minérios restantes) não vem se constituindo como reflexo da desoneração do ICMS, mesmo considerando a redução dos seus custos de produção e, consequentemente, dos seus preços no mercado internacional.

Da mesma forma, não melhorou a performance da balança comercial do Estado. A partir de 1996 passou a ocorrer um decréscimo no saldo da balança comercial do Amapá, mesmo considerando que a partir desse ano também decresceu a importação pelo Estado, fortemente determinada pela Área de Livre Comércio de Macapá e Santana (Gráfico 10).

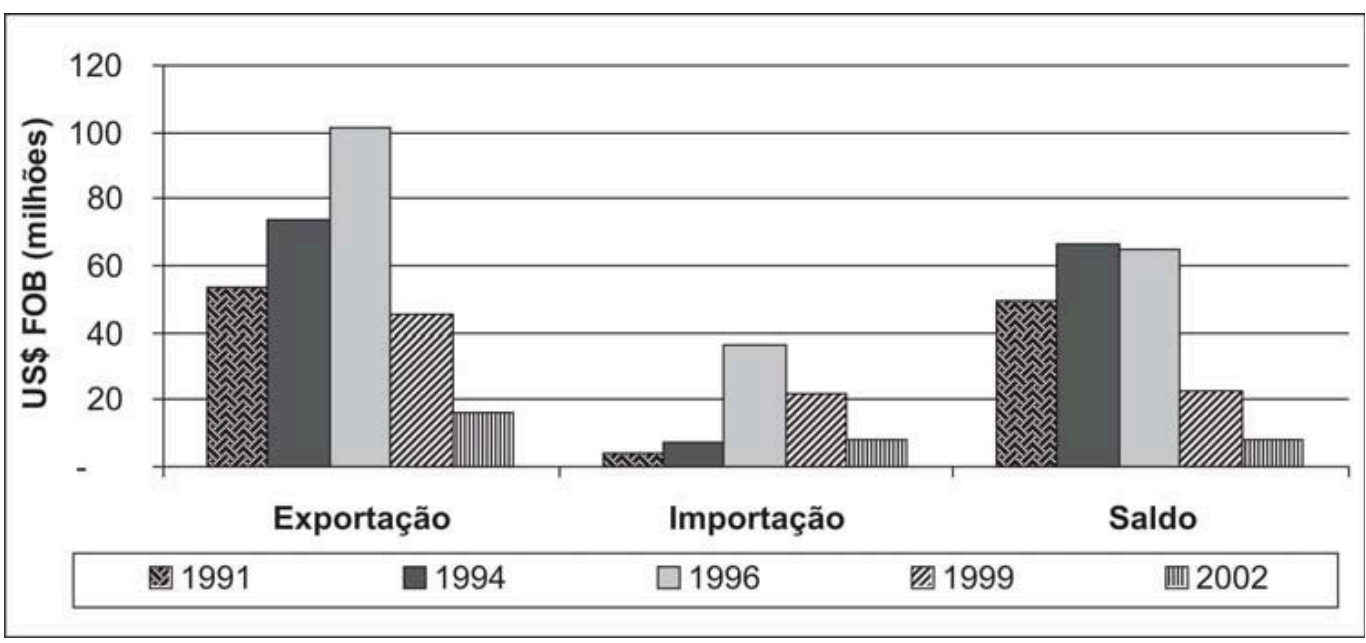

Gráfico 10: Balança comercial do Amapá.

\subsection{Impacto na arrecadação tributária dos Estados}

De acordo com o previsto na LC no 87/1996, o governo federal entregaria mensalmente aos Estados e aos seus municípios, até o exercício financeiro de 2002, os recursos de compensação da desoneração das exportações, com base no produto da arrecadação estadual efetivamente realizada do ICMS no período de julho/1995 a junho/1996.

Pela LC no 102/2000, o governo federal definiu uma mudança na sistemática de entrega desses recursos, determinando previamente os valores a serem ressarcidos aos Estados e municípios (de R $\$ 3,8$ bi no ano 2000 e de $R \$ 3,1$ bi nos anos 2001 e 2002), o índice de atualização desses valores para os anos de 2001 e 2002 (IGP-DI da FVG), e o coeficiente individual de participação de cada Estado e seus respectivos municípios no total dos recursos transferidos (no ano 2000 o Pará teria o índice de 4,36371\%: o Maranhão com 1,6788\%; e o Amapá com $0,40648 \%)$.

Pela LC no 115/2002, ficou definido que essa compensação financeira ocorrerá até 2006, subordinando-se à existência de 
disponibilidades orçamentárias consignadas a essa finalidade na respectiva Lei Orçamentária do governo federal. Em outras palavras, criou um sistema de recomposição parcial das perdas decorrentes da isenção do ICMS, na medida em que os recursos a serem transferidos estarão limitados ao saldo orçamentário previamente definido. Para 2003 ficou definido o valor de $\mathrm{R} \$ 3,9$ bi e para os anos de 2004 e 2005 os montantes a serem ainda consignados no orçamento. Ao mesmo tempo, consolidou os coeficientes individuais de participação dos Estados, com base nos parâmetros definidos para o ano 2000, mantendo-se o Pará, Amapá e Maranhão com os mesmos índices antes definidos.

Por fim, através da Emenda Constitucional no 42/2003, que trata de parte da reforma tributária, incorporou a imunidade de ICMS sobre as exportações de produtos primários e semi-elaborados, sem contudo definir as formas da compensação financeira pelas perdas na arrecadação, visto que isto foi delegada a uma lei complementar que até então, final de 2005, ainda não foi editada.

A reformulação da Lei Kandir só ampliou o impasse entre os Estados exportadores e a União por causa das perdas com o fim da cobrança do ICMS nas exportações. Ao longo desses nove anos de criação desse mecanismo fiscal, há um saldo contabilizado de perda de recursos de R 130 bi aos Estados exportadores, mas que na verdade se reduz para $\mathrm{R} \$ 84$ bi quando se confronta com o ressarcimento já efetuado pela União de R\$ 46 bi até meados de 2005.

O impasse se acirra a cada exercício financeiro em função da previsão e disponibilidade de recursos no orçamento anual da União, como, por exemplo, agora em 2005, que a estimativa de ressarcimento era de $\mathrm{R} \$ 18,2$ bi, mas o que foi orçado prevê o repasse de apenas $\mathrm{R} \$ 2,8$ bi. Para 2006 a União simplesmente não previu recursos no seu orçamento para efetivar o devido ressarcimento das perdas. Isto tem obrigado os Estados a exigirem a compensação integral pelas perdas econômicas, desencadeando um verdadeiro cabo de guerra entre a União e os Estados. No segundo semestre de 2005, os governadores dos Estados do Rio Grande do Sul, Paraná, Santa Catarina e Mato Grosso do Sul a impetrarem uma ação no Supremo Tribunal Federal exigindo a compensação total das perdas, enquanto que os Secretários Estaduais de Fazenda, em reunião no Conselho Nacional de Política Fazendária (Confaz) aprovaram resolução que suspende o pagamento de créditos a empresas exportadoras que cobram dos Estados o reembolso do ICMS pago na compra de equipamentos e insumos utilizados em suas cadeias produtivas.

\section{O caso do Pará}

Segundo dados da Secretaria da Fazenda do Estado do Pará, a perda da receita do ICMS em decorrência dos efeitos provocados pela Lei Kandir 
representou 14\% da receita tributária própria do Estado. A apuração das perdas foi realizada com base no inciso IV do artigo 155 da Constituição Federal, combinado com o artigo 2. ${ }^{\circ}$ da Resolução Federal n. ${ }^{\circ} 22 / 89$, que resumidamente estabelece a aplicação de uma alíquota de $13 \%$ sobre as exportações em todo o país (PANDURO, 2001).

Para se ter uma idéia dessas perdas, será aqui utilizado um levantamento realizado por Panduro (2001), que mostra que, de outubro de 1996 a dezembro de 1999, o Pará deixou de arrecadar R\$ 1,2 bilhão em decorrência da desoneração do ICMS para os produtos primários e os semibeneficiados (Tabela 1). Desse total, $\mathrm{R} \$ 933$ milhões resultaram da desoneração dos produtos minerais (78\% do total).

Tabela 1: Pará: demonstrativo de cálculo das perdas diretas de arrecadação do ICMS nas exportações dos principais produtos do Estado (1996-1999).

\begin{tabular}{lr|r|r|r}
\hline \multicolumn{1}{c|}{ PRODUTOS } & out-dez 1996 & jan-dez 1997 & jan-dez 1998 & jan-dez 1999 \\
\hline \multicolumn{1}{c}{ MINERAIS } & $\mathbf{4 7 . 9 0 4}$ & $\mathbf{2 4 6 . 5 5 7}$ & $\mathbf{2 5 8 . 8 7 2}$ & $\mathbf{3 7 9 . 2 7 2}$ \\
\hline Minério de ferro & 20.796 & 101.836 & 113.108 & 155.170 \\
Aluminio e derivados & 16.645 & 77.447 & 68.108 & 107.155 \\
Alumina e óxidos & 2.744 & 9.005 & 19.325 & 30.815 \\
Caulim & 2.712 & 11.669 & 15.885 & 28.816 \\
Bauxita & - & 15.529 & 17.027 & 23.570 \\
Ouro & 2.784 & 17.290 & 12.134 & 19.998 \\
Manganês & 997 & 4.230 & 6.312 & 5.757 \\
Ferro-gusa & 249 & 5.585 & 4.726 & 5.843 \\
Silicio & 976 & 3.913 & 2.246 & 2.598 \\
\hline \multicolumn{1}{c}{ TRADICIONAIS } & $\mathbf{1 7 . 3 2 2}$ & $\mathbf{6 9 . 4 3 9}$ & $\mathbf{7 3 . 1 0 7}$ & $\mathbf{1 2 0 . 6 4 4}$ \\
\hline Madeira & 10.827 & 46.316 & 38.460 & 65.222 \\
Pasta quimica de madeira & 2.593 & 6.066 & 12.605 & 23.075 \\
Pimenta & 2.115 & 6.892 & 11.120 & 18.068 \\
Castanha-do-brasil & 166 & 2.791 & 2.332 & 1.790 \\
Camarão congelado & 452 & 2.557 & 3.578 & 5.690 \\
Dendê & 496 & 2.142 & 1.284 & 2.001 \\
Cacau & 12 & - & - & - \\
Palmito em conserva & - & 1.697 & 1.674 & 1.758 \\
Peixes & 41 & 177 & 272 & 823 \\
Movéis e art. madeira & - & 494 & 510 & 852 \\
Couros e peles & 95 & 308 & 161 & 184 \\
Suco de frutas & 524 & 181 & 53 & 1.178 \\
\hline \multicolumn{1}{c}{ SUBTOTAL } & $\mathbf{6 8 . 6 5 1}$ & $\mathbf{3 1 5 . 9 9 5}$ & $\mathbf{3 3 1 . 9 7 8}$ & $\mathbf{5 0 0 . 3 7 1}$ \\
\hline Outros produtos & 3.425 & 1.028 & 1.141 & 2.590 \\
\hline \multicolumn{1}{r}{ TOTAL } & $\mathbf{6 8 . 6 5 1}$ & $\mathbf{3 1 7 . 0 2 4}$ & $\mathbf{3 3 3 . 1 1 9}$ & $\mathbf{5 0 2 . 9 6 1}$ \\
\hline
\end{tabular}

Fonte: Cálculos efetuados por Panduro (2001), com base nos dados do Sistema ALICE/ SECEX.

Ocorre que a LC n. ${ }^{\circ}$ 87/96 criou um mecanismo para garantir a manutenção do nível de receitas do ICMS relativo ao período de julho de 1995 a junho de 1996, que serviria para comparar as arrecadações 
posteriores à sua implementação. Na prática, serviu como uma compensação das perdas dos estados, visto que, se essa arrecadação posterior fosse inferior àquela observada nesse período, haveria ressarcimento da perda. Daí a denominação de "seguro-receita".

Assim sendo, no período de outubro de 1996 a dezembro de 1999, o Pará recebeu, como ressarcimento, o equivalente a R\$379 milhões, o que amortizou o correspondente a $45 \%$ do valor total que deixou de ser contabilizado na receita do Estado em função da desoneração do ICMS. Com isso, compensando-se esses valores, constata-se que a perda real efetiva por conta da desoneração foi em torno de R\$ 842 milhões. Como as perdas são calculadas em relação ao período-base definido pela Lei, verifica-se também que, à medida que o Estado aumenta a eficiência de sua arrecadação, diminui o valor que lhe é repassado sob a forma de ressarcimento das perdas, o que na prática penaliza o Estado.

Pelos dados do Balanço Geral do Estado, apresentados no Gráfico 11, verifica-se que mesmo a perda provocada pela desoneração do ICMS não impediu que a eficiência da arrecadação do Estado aumentasse a sua receita tributária ao longo desse período: a receita própria expandiuse, tendo passado de R 978 milhões em 1994 para R \$ 1,3 bilhão em 1999 (o súbito crescimento apresentado em 1998 refere-se à receita proveniente da privatização da empresa de energia do Estado), apesar da queda ocorrida na arrecadação do ICMS - o crescimento da receita desse imposto a partir de 1998 ainda não conseguiu alcançar o patamar do valor arrecadado em 1996, antes da aplicação da Lei Kandir.

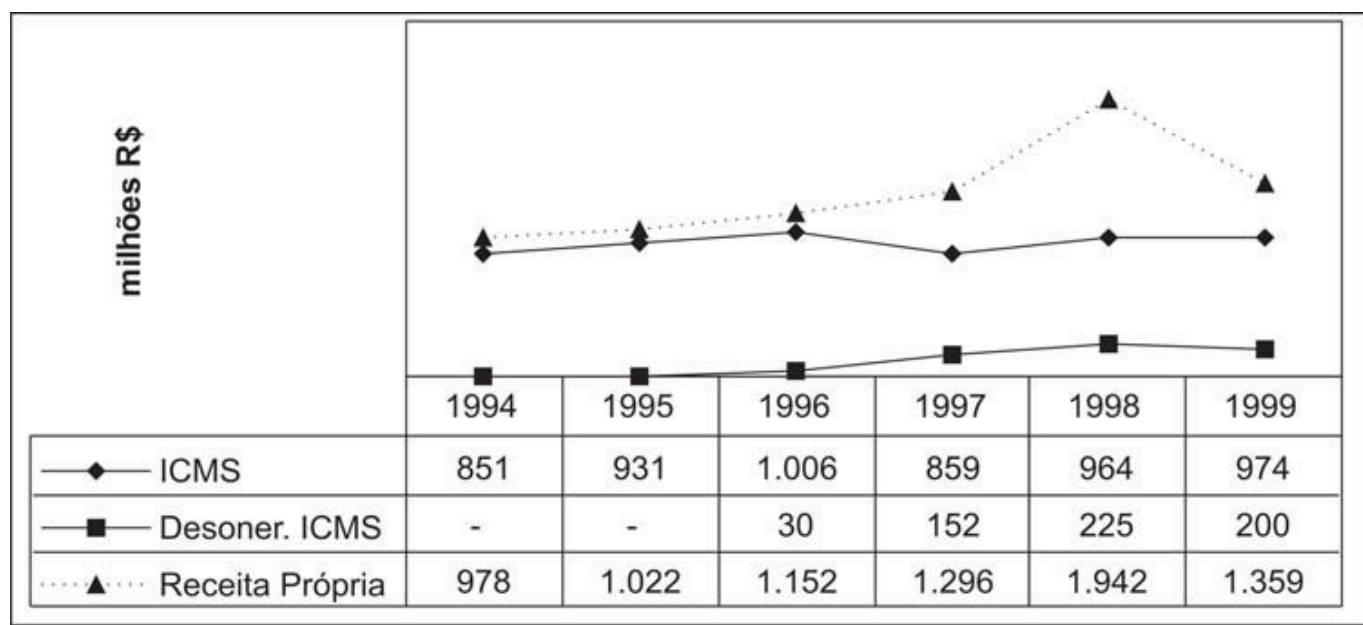

Gráfico 11: Pará: evolução da receita estadual.

Com a incidência da desoneração em alguns setores específicos da economia paraense, a arrecadação do ICMS, ex-post à Lei Kandir, passou a provir de setores econômicos tradicionais - como produtos alimentícios e bebidas, extração e beneficiamento de madeira -, e de setores vinculados ao setor terciário - comércio atacadista, varejista e atividades recreativas 
e culturais (Gráfico 12). Esses subsetores geram ICMS em valores muito mais expressivos do que os arrecadados pela produção dos subsetores de extração de minerais metálicos e não-metálicos.

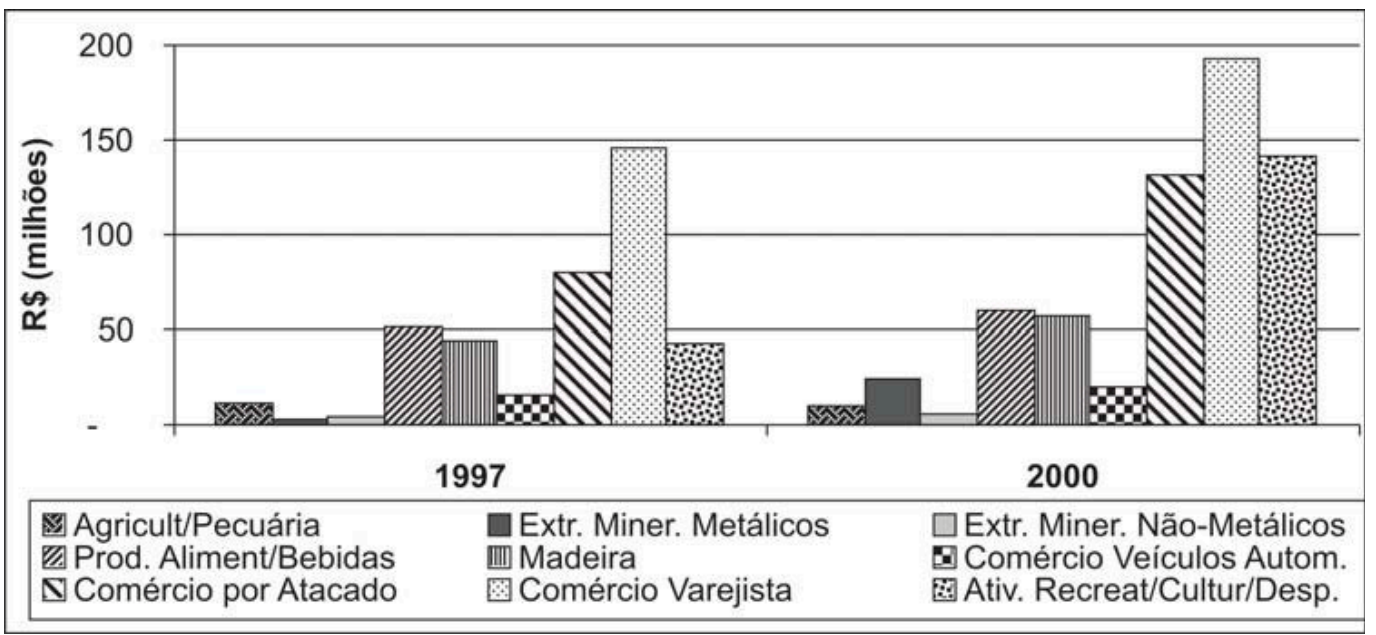

Gráfico 12: Pará: ICMS arrecadado por subsetor econômico.

\section{O caso do Maranhão}

A Gerência da Receita Estadual do Maranhão (GERE) não tem os cálculos das perdas decorrentes da desoneração do ICMS nas exportações de produtos primários ou semibeneficiados do Estado, nem tampouco tem a mínima idéia de quanto isso representa no caso específico dos produtos minerais. Os técnicos da GERE do Maranhão sabem que o Estado tem perdas, até mesmo porque, de forma geral, o ressarcimento efetuado pelo governo federal só cobre parte do valor que é desonerado em cada Estado. Todavia, ainda não computaram o que não tem sido recolhido a cada mês (pela declaração de saídas para o exterior, por operações locais permitidas pela legislação ou por meio do sistema de compensação existente), nem fizeram qualquer confronto com o valor ressarcido pela União; portanto, desconhecem o saldo resultante. Se isso fosse feito, seria possível detectar, de forma aproximada, qual a perda do Maranhão com os efeitos da Lei Kandir.

Para se ter uma idéia dessas perdas, utilizar-se-á aqui uma informação contida nos cálculos efetuados pela Comissão Técnica Permanente do ICMS, responsável pelos cálculos dos débitos do ICMS desonerados nas saídas para o exterior, para todas as unidades da Federação, relativos ao ano de 2001. No caso do Maranhão, o Estado deixou de arrecadar o montante de R\$166,2 milhões de ICMS por conta do que foi exportado ( $\mathrm{R} \$ 1,3$ bilhão), tanto em relação aos produtos minerais quanto aos demais produtos semibeneficiados e produtos primários. A União ressarciria o Estado em 2002 com R\$ 39,6 milhões, pelo Fundo Orçamentário, e mais R\$22,5 milhões, pelo Fundo de Exportação (FPEX), em um total de R\$ 62,1 milhões. Conseqüentemente, 
o débito de ICMS não ressarcido para o Maranhão seria de R 104,1 milhões, o que representaria sua perda total correspondente a 2001, com a Lei Kandir. E isso apenas em relação às declarações de saídas de produtos para o exterior.

Por conta da desoneração, os empreendimentos minerais não se destacam como contribuintes de impostos relevantes no Maranhão. Na listagem dos 200 maiores contribuintes de ICMS do Estado, em 2002, a Petrobrás aparece como a maior contribuinte, com 15,2\% do total arrecadado nesse ano, seguida pela Telemar, com 8,7\%, e pela Companhia Energética do Maranhão (CEMAR), com 6,2\%. A CVRD, com duas inscrições registradas, contribui com 3,1\% e 1,5\% (totalizando 4,6\%), a Alcoa Alumínio SA com 1,9\%, a Billiton Metais SA com 0,9\%, a Alcan Alumínio do Brasil Ltda com menos de 0,1\%, e a Aço Maranhão também com menos de $0,1 \%$. Os demais empreendimentos contribuintes relevantes são supermercados, atacadistas, cervejarias, companhias de transportes, etc.

\section{O caso do Amapá}

A equipe técnica da Secretaria da Fazenda do Amapá também não tem efetuado os cálculos decorrentes das perdas com a Lei Kandir no Estado. O que é de conhecimento do Órgão resulta dos quadros repassados pela Comissão Técnica Permanente do ICMS. Localmente se sabe que a madeira é o produto que mais tem causado desoneração do ICMS, mas não se tem o devido controle sobre esse procedimento, tampouco sobre os demais produtos desonerados. Os produtos minerais que são beneficiados pela desoneração não constam das estatísticas do Órgão, pois são computados com códigos diferentes do grupo de produtos a que pertencem.

De acordo com os dados da Comissão Técnica, relativos ao ano de 2001, pelo valor das exportações efetuadas pelo Estado nesse ano, foi desonerado o equivalente a R\$ 9,3 milhões. Em 2002 deveria a União ressarcir o Estado no valor de R 7,2 milhões, pelo Fundo Orçamentário, e mais R $\$ 432$ mil, pelo FPEX. Com isso, o débito de ICMS não ressarcido seria de apenas R\$ 1,7 milhão. Como essa diferença representa menos de $20 \%$ do total do que foi desonerado pelo Estado (o que se diferencia da realidade dos demais estados), talvez isso não estimule o governo local a estar permanentemente acompanhando as perdas, o que é bem diferente do que ocorre no Pará.

\subsection{Impacto na arrecadação tributária dos municípios}

As perdas decorrentes da desoneração do ICMS refletem também nos municípios, visto que esse imposto é rateado entre o Estado e as instâncias municipais. Ocorre que o impacto é mais profundo nos 
municípios, visto que o repasse desse imposto para a formação da receita tributária dos municípios é intermediado por um mecanismo conhecido como valor adicionado ${ }^{16}$, que sofreu alterações substanciais após a Lei Kandir.

\section{O caso do Pará}

Em um primeiro momento, as alterações realizadas após a vigência da Lei Kandir ocorreram no ICMS arrecadado por município. Isto é, naqueles municípios cuja arrecadação do ICMS era, até então, na sua quase totalidade, oriunda da produção ou da comercialização dos produtos minerais (e de energia elétrica) vinculados aos grandes empreendimentos industriais, houve uma redução acentuada no recolhimento desse imposto. Conforme demonstrado no Gráfico 13, que evidencia a situação desses municípios, sede dos grandes empreendimentos minerais existentes no Pará, verifica-se que, logo após a incidência dessa Lei, houve uma queda expressiva na arrecadação desse imposto, que só se recuperou a partir de 1999. No caso específico do município de Parauapebas, onde se localizam os projetos de exploração de minério de ferro, manganês e outros, de propriedade da CVRD, a recuperação que ocorreu a partir de 1999 é extremamente lenta e nem sequer representa 1/5 do valor que vinha sendo arrecadado antes da vigência da Lei.

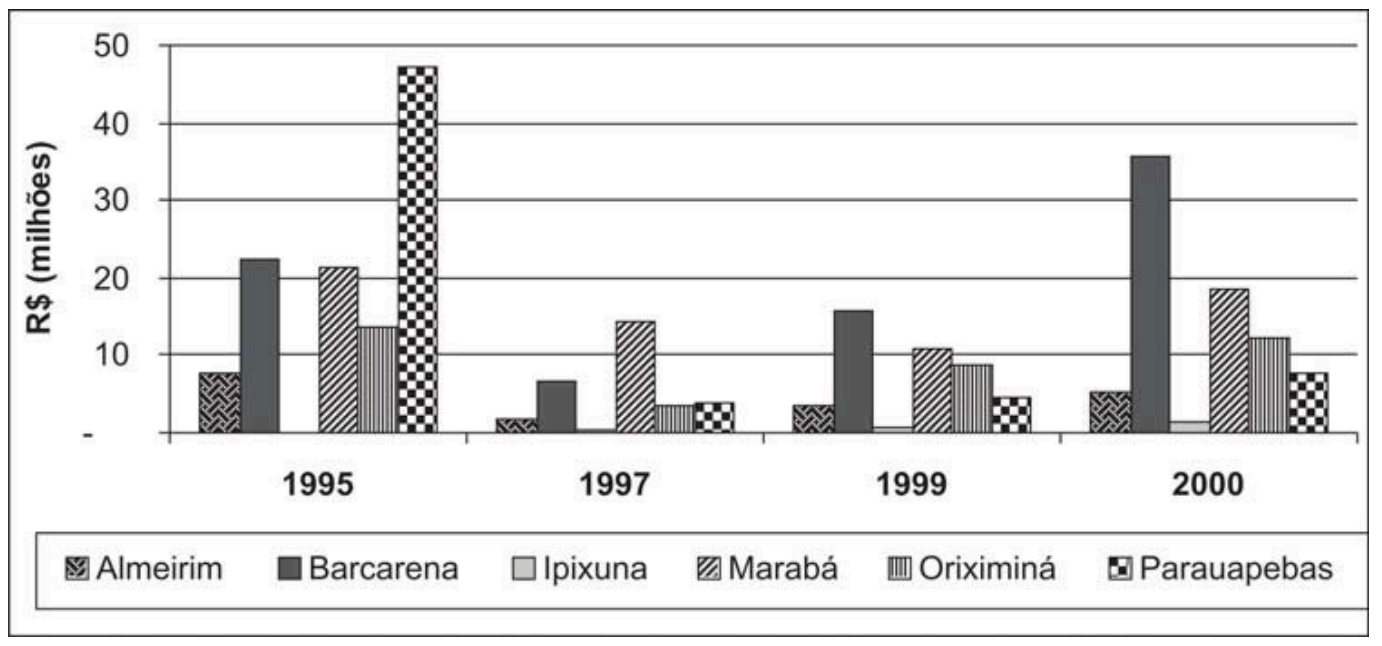

Gráfico 13: Pará: ICMS arrecadado por município.

Isso se torna extremamente problemático quando, no momento em que se calcula o valor do ICMS a ser repassado a cada município, é aplicado o princípio do valor adicionado. Por essa regra, quanto maior

\footnotetext{
${ }^{16}$ De acordo com a Lei Complementar n. ${ }^{\circ}$ 63, de 11 de janeiro de 1990, o valor adicionado corresponde, para cada município, ao valor das mercadorias saídas, acrescido do valor das prestações de serviços, no seu território, deduzido o valor das mercadorias entradas, em cada ano civil. O Estado apura a relação percentual entre o valor adicionado em cada município e o valor total do Estado, aplicando esse índice quando da entrega das parcelas do ICMS que cabem aos municípios.
} 
for o nível de agregação de valor em um município, maior será o valor de redistribuição do ICMS para esse município, isto é, quanto mais valor adicionado for gerado em um município, maior será a sua cota-parte do ICMS, independentemente da sua parcela de contribuição para o total do valor do ICMS arrecadado no Estado, visto que a sua participação no rateio de distribuição se dá sobre o total da arrecadação do Estado e não sobre a arrecadação realizada diretamente no seu território; além do mais, para o cálculo do valor adicionado, é contabilizado o valor do imposto desonerado, como se ele tivesse sido efetivamente pago.

Para efeito de visualização da importância desse princípio que determina em que base ocorrerá a redistribuição do ICMS para os municípios, utilizar-se-ão os dados pertinentes à área polarizada economicamente pelo município de Parauapebas (Gráfico 14). Verificase, de forma bem simples, que o valor adicionado correspondente a Parauapebas é extremamente elevado em comparação com o dos demais municípios da sua área de entorno, os quais não apresentam praticamente valor adicionado, com exceção de Marabá.

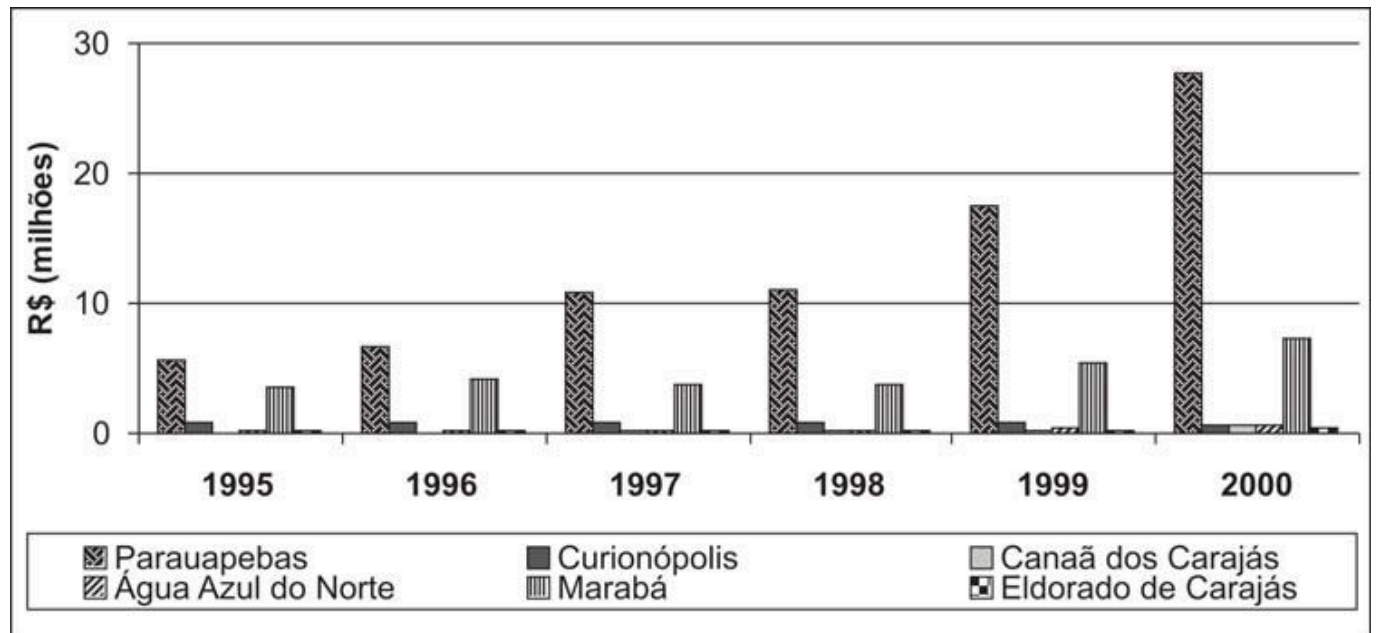

Gráfico 14: Pará: valor adicional por município.

Em termos hipotéticos, poder-se-ia dizer que, se o ICMS repassado para os municípios se resumisse aos municípios dessa área, Parauapebas teria direito, em média, a cerca de $75 \%$ do total transferido pelo Estado, Marabá, a aproximadamente 18\%, e o restante seria dividido entre os demais municípios. Em resumo, a desoneração do ICMS deixa de gerar mais receita tributária para os municípios e, quando a regra do valor adicionado contabiliza a desoneração como crédito, propicia perdas duplicadas, triplicadas ou quintuplicadas para os municípios que não conseguem incentivar ou realizar a industrialização de sua economia e que, portanto, sobrevivem à base da produção tradicional assentada na agricultura ou nas atividades extrativas. 
Os dados constantes nos Gráficos 15 e 16 retratam, em termos reais, essa situação. No caso do eixo polarizado por Parauapebas, observa-se que esse município é o que apresenta a melhor performance em termos de ICMS transferido; verifica-se ainda que, a partir de 1997, a trajetória da sua receita fez uma inflexão ascendente em relação à dos demais municípios, distanciando-se cada vez mais dos demais. Isto é, Parauapebas ampliou demasiadamente a sua participação em detrimento dos demais municípios da sua área de entorno, assim como dos demais municípios do Estado, já que o rateio é feito entre todos os municípios paraenses.

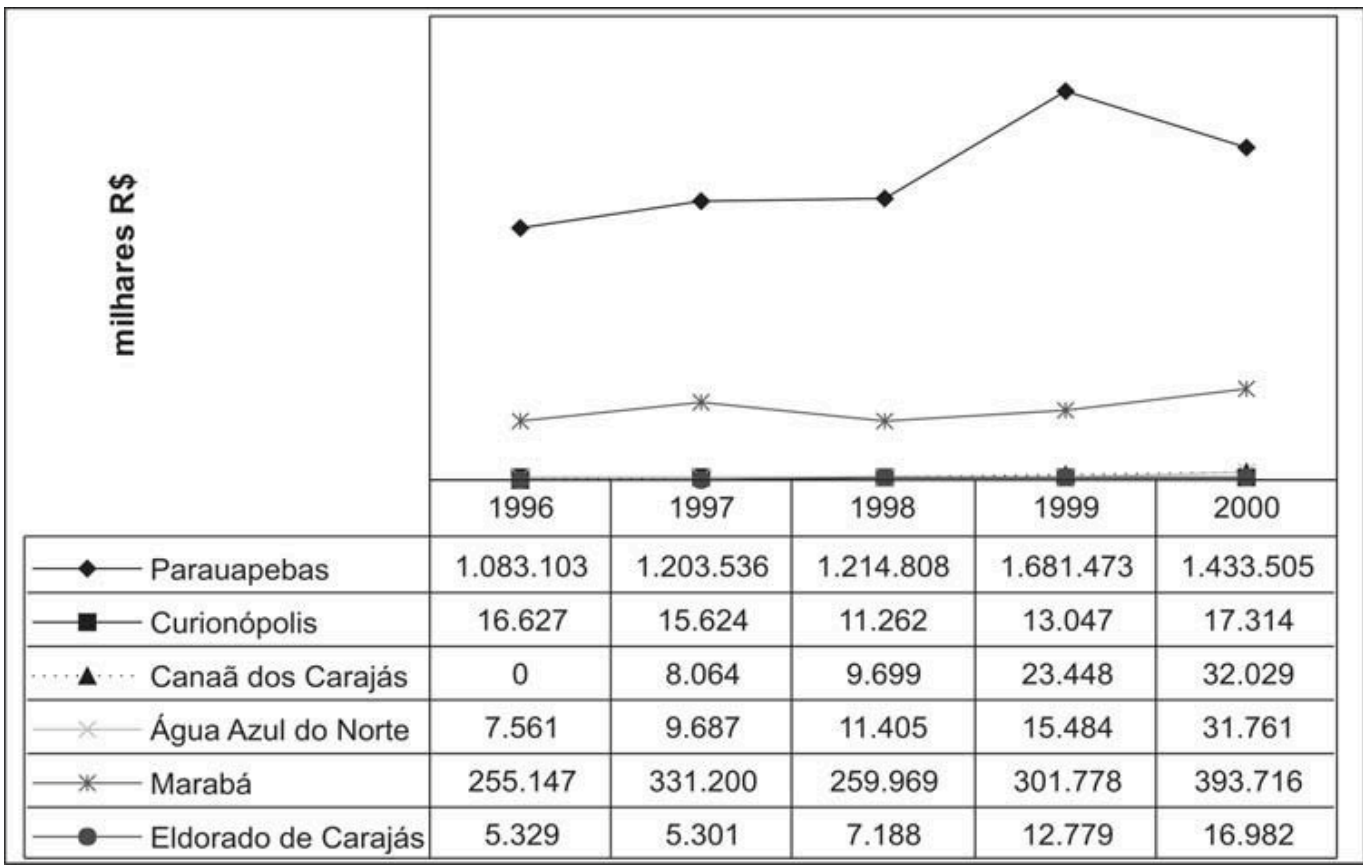

Gráfico 15: Pará: ICMS transferido aos municípios.

\begin{tabular}{|c|c|c|c|c|c|c|}
\hline \multirow[t]{2}{*}{ 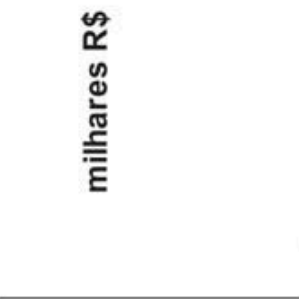 } & $x=$ & $x$ & $x$ & $\bar{x}$ & $z=$ & - \\
\hline & 1995 & 1996 & 1997 & 1998 & 1999 & 2000 \\
\hline$\longrightarrow$ Barcarena & 5.993 & 6.953 & 6.703 & 6.852 & 8.477 & 10.853 \\
\hline$\Longrightarrow$ Abaetetuba & 728 & 845 & 855 & 874 & 1.000 & 1.309 \\
\hline … Mojú & 352 & 408 & 369 & 377 & 508 & 705 \\
\hline X Acará & 352 & 409 & 369 & 377 & 533 & 630 \\
\hline
\end{tabular}

Gráfico 16: Pará: ICMS transferido aos municípios.

O mesmo ocorreu no eixo polarizado pelo município de Barcarena, onde se encontram os projetos da ALBRÁS, da ALUNORTE e empresas 
do caulim - Pará Pigmentos SA (PPSA) e Imerys Capim Caulim (ICC). Barcarena tem aumentado a sua participação no rateio do ICMS, principalmente a partir de 1998, quando já se encontrava em operação a produção de alumina, enquanto os demais municípios desse eixo têm mantido praticamente o mesmo valor que lhes é transferido pelo Estado.

\section{O caso do Maranhão}

Diferentemente do caso do Pará, onde a produção mineral está localizada em áreas distintas e distantes da capital do Estado, o que, portanto, provoca impactos mais significativos nos demais municípios, no Maranhão a produção mineral está distribuída da seguinte forma: a ALUMAR está instalada em São Luís, a capital do Estado, e os empreendimentos siderometalúrgicos em Açailândia e Imperatriz, basicamente.

Principalmente pelo fato de o mais importante empreendimento desse setor (a ALUMAR) estar localizado na capital do Estado, o efeito mais expressivo, em termos de arrecadação tributária, incide justamente em São Luís, penalizando o interior do Estado. Do total do ICMS arrecadado nos 217 municípios existentes no Maranhão, São Luís é responsável por cerca de 63\%, seguido de Imperatriz, com 4\% (mas caindo ao longo dos anos), e de Açailândia, cuja participação, que era de aproximadamente 1\%, aumentou, passando para quase 4\% em 2002 (Gráfico 17).

No período de 1998 a 2002, anos para os quais há estatísticas disponíveis na GERE-MA, observa-se um crescimento nominal e real da arrecadação realizada no município de São Luís, o que, juntamente com a arrecadação de Açailândia, tem determinado uma redução percentual da participação dos demais municípios do Estado, cuja participação já foi de 36\% e em 2002 se encontrava em 28\%.

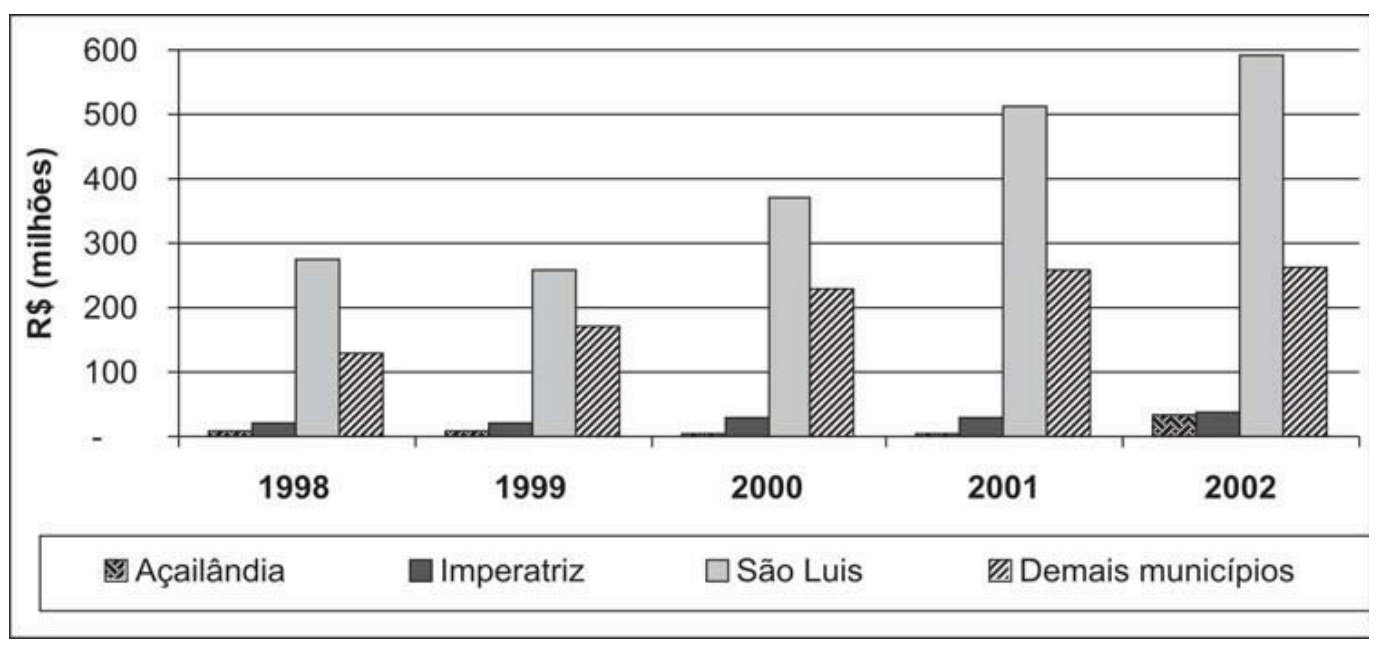

Gráfico 17: Maranhão: ICMS arrecadado por município.

Nesse particular, é interessante assinalar que, de acordo com os registros do próprio governo, existem 884 indústrias de transformação 
estabelecidas em São Luís, o que representa 46\% do total de empresas existentes no Estado. Isso significa dizer que: primeiro, com a implantação de indústrias do ramo mineral no Maranhão, São Luís não perdeu a sua importância estratégica na economia local; segundo, com a implantação da ALUMAR em São Luís, a capital do Estado adquiriu ainda maior importância econômica, concentrando cada vez mais o produto interno bruto estadual. Por conseqüência, diminuiu ou restringiu-se o espraiamento do desenvolvimento para os demais espaços geoeconômicos do Estado.

A melhor demonstração desse fato pode ser encontrada nos registros do valor adicionado realizado no Estado. Em 1995, São Luís era responsável por 60\% do valor adicionado de todo o Estado, mas nos anos seguintes esse percentual foi evoluindo, atingindo um pouco mais de 71\% em 2001 (situação idêntica à de 1999, muito embora em 2000 tenha alcançado um patamar maior). A participação do restante dos municípios do Estado tem decrescido: excluindo-se Açailândia (que quase duplica a sua participação no período) e Imperatriz (cuja participação tem diminuído, lentamente), a participação dos demais municípios diminuiu pela metade, em termos reais, pois, enquanto em 1995 essa participação era de 28\%, em 2001 foi de apenas 14,6\% (Gráfico 18).

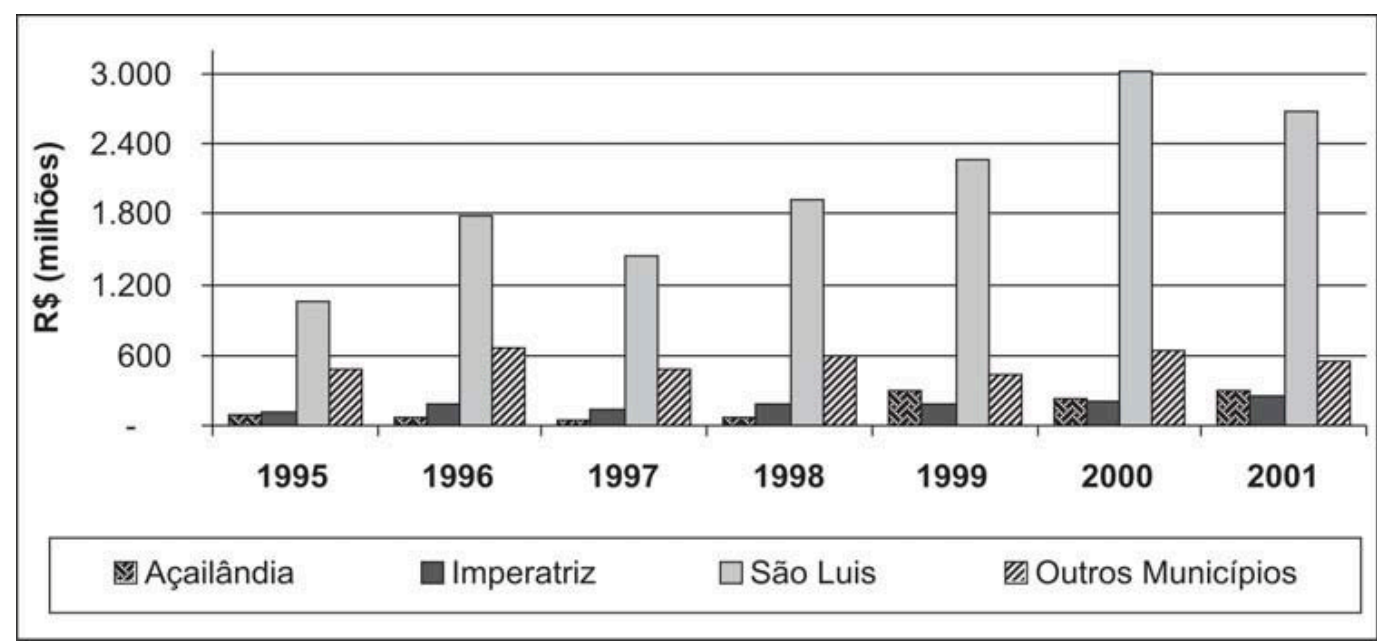

Gráfico 18: Maranhão: valor adicional por município.

Considerando-se que o valor adicionado de cada município é o que determina o correspondente a, no mínimo, 75\% da cota-parte do ICMS que é redistribuído a cada município e que, além disso, como já

\footnotetext{
${ }^{17}$ No Maranhão, a cota-parte do ICMS redistribuído aos municípios é calculada na seguinte proporção e de acordo com os seguintes critérios: 3/4 de acordo com o valor adicionado e 1/4 de acordo com o que dispõe a Lei Estadual n. ${ }^{\circ}$ 5.599, de 24 de dezembro de 1992 (correspondente a $25 \%=15 \%$ divididos em partes iguais entre todos os municípios, $5 \%$ de acordo com a relação população do município/população do Estado e 5\% segundo a relação território do município/território do Estado).
} 
foi dito, para o cálculo do valor adicionado é contabilizado o valor do imposto desonerado como se ele tivesse sido efetivamente pago, a capital do Estado do Maranhão, São Luís, tem-se apropriado, cada vez mais, da maior parcela do ICMS redistribuído aos municípios. De acordo com o Gráfico 19, em 1999 essa parcela correspondia a 50,5\% do total, mas foi 52,5\% em 2000, 53,7\% em 2001 e 55,3\% em 2002. A parcela do município de Açailândia quase dobrou no período, pois passou de 2,9\% para 5,6\%. Entretanto, a participação do conjunto restante dos municípios diminuiu de 46,6\% para 39,1\%. Em suma, o interior do Estado recebeu menos recursos financeiros oriundos do ICMS, não somente porque diminuiu o volume do imposto recolhido pelo Estado (por conta da desoneração), mas também porque diminuiu relativamente o valor agregado realizado no interior (em comparação com o ocorrido na capital, por conta principalmente da atuação da ALUMAR).

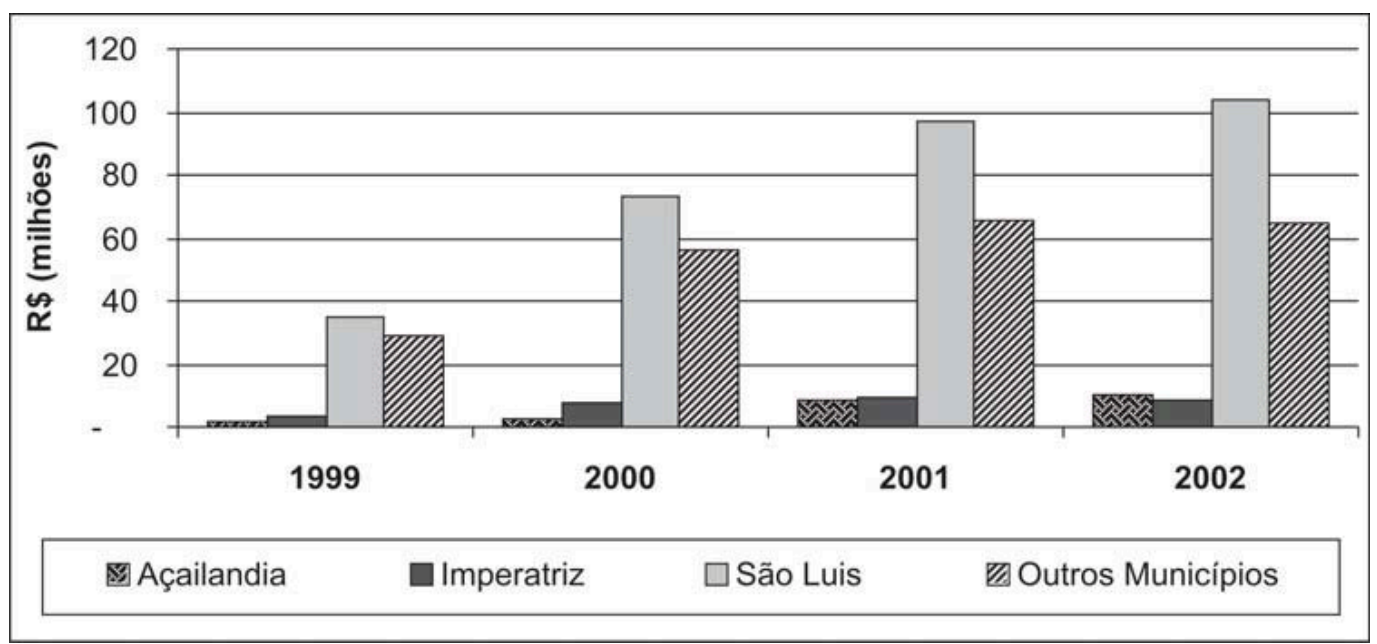

Gráfico 19: Maranhão: ICMS redistribuído aos municípios.

\section{O caso do Amapá}

No Amapá, é bastante complexo verificar os efeitos da Lei Kandir na arrecadação municipal, principalmente no que concerne à indústria de mineração. Primeiro, porque a mineração já não desempenha um papel de relevância econômica no Estado; segundo, porque, em decorrência da falta de acompanhamento dessa questão pela fazenda estadual, fica difícil inferir com precisão quem ganha e quem perde no rateio dos recursos transferidos; terceiro, porque a fazenda estadual não sabe efetuar adequadamente os cálculos correspondentes ao valor adicionado realizado no Estado.

Essa última questão resulta da complexidade do critério adotado pelo Estado para definir de que forma redistribui a parcela correspondente a $1 / 4$ dos $25 \%$ do ICMS pertencentes aos municípios. Diferentemente da realidade do Pará e do Maranhão, o Amapá 
determinou, por meio da Lei Estadual n. ${ }^{\circ}$ 0322/96, que essa parcela seria calculada com base nos seguintes critérios: área geográfica, população, população dos três municípios mais populosos, educação, área cultivada, patrimônio cultural, meio ambiente, gastos com saúde, cota mínima e receita própria, a Secretaria de Estado de Planejamento (SEPLAN) assumindo a responsabilidade de publicação desse índice.

Ocorre que nem a SEPLAN, nem tampouco a Secretaria da Fazenda (SEFAZ) sabem calcular esse índice com base em todos esses critérios, ou, mais propriamente, não dispõem dos índices correspondentes a cada um desses critérios. Em outras palavras, o Estado criou uma forma de cálculo que nem mesmo ele sabe aplicar. Portanto, o índice que corresponde à cota-parte de cada município do Amapá é definido sem a precisão devida e sem a segurança das informações que formam a base de cálculo da arrecadação do Estado. Isso acabou até por levar a fazenda estadual a definir os índices de redistribuição do ICMS para os municípios, para o ano de 2004, usando os mesmos índices definidos para o ano anterior, de 2003, sem nenhuma alteração.

Mas, independentemente dessas questões, é importante evidenciar que, com base nos índices definidos para os anos anteriores, o município de Macapá, capital do Estado, tem auferido o equivalente a 58\% do total transferido aos municípios, vindo a seguir o município de Santana, justamente os municípios que abrangem a ALCMS. Juntos, absorvem mais de 80\% do valor do ICMS transferido (Gráfico 20).

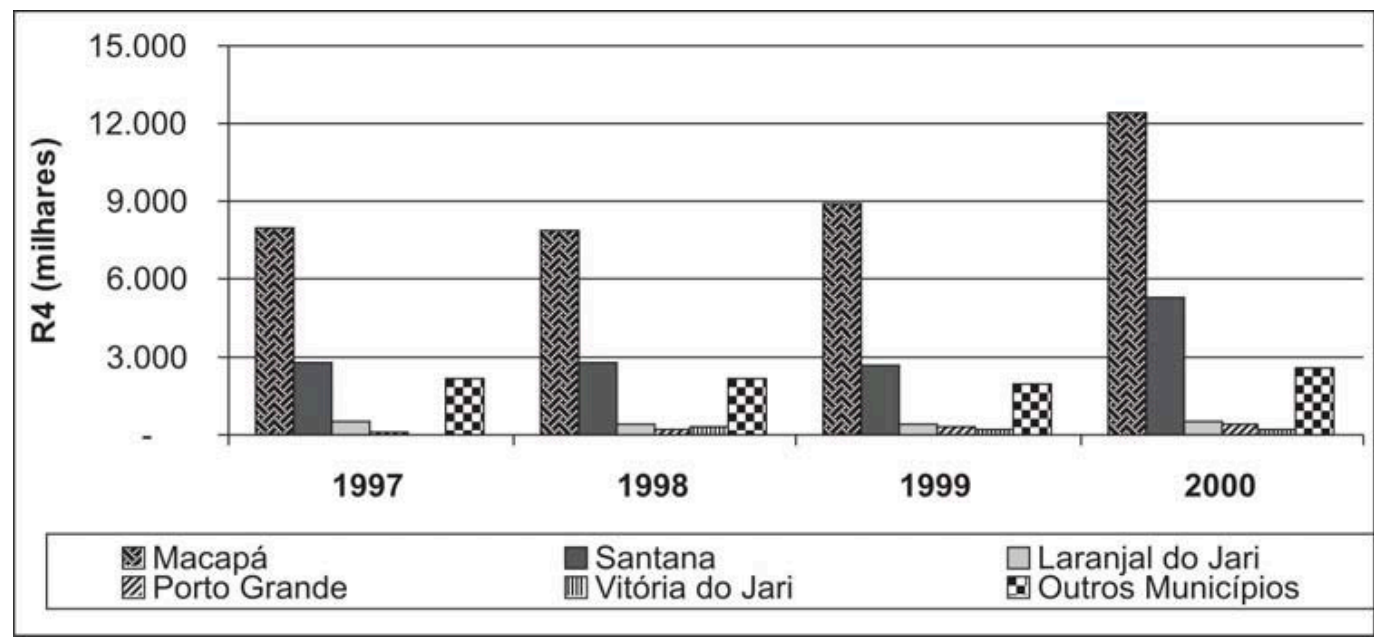

Gráfico 20: Amapá: ICMS redistribuído aos municípios.

\section{CONCLUSÃO}

Em geral, qualquer ângulo de análise ou qualquer base teórica evidencia que é imprescindível, para o desenvolvimento de uma economia, que ocorra uma agregação de valor. Nos moldes capitalistas, é fundamental que essa agregação aconteça de forma estruturada em uma produção industrializada. Apoiando-se nesse princípio ou nessa 
tese desenvolvimentista à la Cepal e precisando de mecanismos que ao mesmo tempo propiciassem captação, geração e economia de divisas externas, a fim de melhorar o saldo da balança comercial brasileira, o governo brasileiro criou as condições necessárias para que a Amazônia abrigasse inúmeros projetos industriais, de porte e de natureza diferentes dos existentes na região e voltados basicamente para o atendimento do mercado internacional.

Como o principal instrumento de ação governamental foi e continua sendo o uso de incentivos tributários e financeiros, é evidente que o pacto federativo estabelecido entre os entes federativos existentes no país foi alterado. Como essa alteração não se apresentou uniforme ao longo do tempo, um ou mais entes tiveram de abrir mão de uma maior receita tributária em benefício dos demais entes federativos. Portanto, o que se verificou neste trabalho é que, de acordo com os objetivos da política econômica, foi concebida uma estratégia diferenciada para o desenvolvimento da região, que contribuiu ora para aumentar, ora para reduzir a receita tributária, seja a que se refere à parcela que cabe aos governos estaduais, seja a parcela que pertence aos municípios.

O mais importante, todavia, é que, em ambas as situações, os maiores beneficiados foram os setores produtivos, principalmente os subsetores vinculados à mineração industrial existentes no Pará. Em quaisquer das estratégias adotadas pelo governo, a mineração industrial conseguiu usufruir benefícios que sempre propiciaram o rebaixamento do seu custo de produção e, conseqüentemente, o aumento de sua lucratividade. Aliás, nada mais diferente do que estava concebido ou previsto na estratégia nacional de desenvolvimento regional posta em prática na Amazônia.

Porém, se, em um primeiro momento, isso foi fundamental para atrair os empreendimentos capitalistas para a região, em um segundo momento, pouco concorreu para dinamizar ou ampliar a produção industrial regional (estadual), pois a lógica ou os determinantes que influenciam o tipo de indústria que tem dinamizado a região são exógenos à economia nacional, regional ou local. Por conseguinte, nada foi alterado em termos da produção industrial, mas os entes federativos estadual e municipal têm acumulado prejuízos financeiros, ao contrário de períodos anteriores.

A manutenção dessa situação apóia-se no princípio da integração competitiva, e, como isso se sobrepõe ao princípio da integração regional, que não tem prazo para ser substituído como estratégia de desenvolvimento econômico, a perspectiva é a da reprodução contínua desse quadro, o que provoca uma agudização na diferenciação já existente entre o nível de desenvolvimento da economia local e o da economia nacional, por um lado, e entre os subespaços estaduais, por outro lado. Portanto, a superação desse quadro requer a adoção ou o estabelecimento de um novo modelo de desenvolvimento ou, no mínimo, de um novo pacto federativo no país. Cabe esperar que o futuro chegue, o mais breve possível. 


\section{REFERÊNCIAS}

AMARAL FILHO, Jair do. Desenvolvimento Regional Endógeno: (re) construção de um conceito, reformulação das estratégias. Revista Econômica do Nordeste. Fortaleza: BNB, v. 26, n. 3, p. 325-346, jul/set 1995.

ARAÚJO, Tânia Bacelar de. Brasil nos anos noventa: opções estratégicas e dinâmica regional. Revista Brasileira de Estudos Urbanos e Regionais, Recife: ANPUR, A.1, n.2, p. 9-24, mar, 2000.

IDESP. Impacto de implantação do pólo siderúrgico na estrutura produtiva e no movimento migratório em Marabá. Belém, 1988. (Relatórios de Pesquisa, 12)

MINISTÉRIO DO DESENVOLVIMENTO, INDÚSTRIA E COMÉRCIO. Sistema de Análise das Informações de Comércio Exterior da Secretaria de Comércio Exterior - Secex. ALICEWEB. Disponível em: http:// aliceweb.mdic.gov.br. Acesso em; 25 jun. 2002.

PANDURO, Miguel Angel Del Valle. O impacto da desoneração das exportações brasileiras na arrecadação do ICMS no Estado do Pará. 2001. Monografia (Graduação em Economia) - UFPA, Belém.

SUDAM. II Plano de Desenvolvimento da Amazônia: detalhamento do II Plano Nacional de Desenvolvimento (1975-79). Belém, 1976. 